\title{
Pharmacokinetic and Pharmacodynamic Considerations for Drugs Binding to Alpha-I-Acid Glycoprotein
}

\author{
Sherri A. Smith ' (D) - Nigel J. Waters ${ }^{2}$
}

Received: 5 September 2018 / Accepted: 28 November 2018 / Published online: 28 December 2018

(C) Springer Science+Business Media, LLC, part of Springer Nature 2019

\begin{abstract}
According to the free drug hypothesis only the unbound drug is available to act at physiological sites of action, and as such the importance of plasma protein binding primarily resides in its impact on pharmacokinetics and pharmacodynamics. Of the major plasma proteins, alpha-1-acid glycoprotein (AAG) represents an intriguing one primarily due to the high affinity, low capacity properties of this protein. In addition, there are marked species and age differences in protein expression, homology and drug binding affinity. As such, a thorough understanding of drug binding to AAG can help aid and improve the translation of pharmacokinetic/pharmacodynamic (PK/PD) relationships from preclinical species to human as well as adults to neonates. This review provides a comprehensive overview of our current understanding of the biochemistry of AAG; endogenous function, impact of disease, utility as a biomarker, and impact on $\mathrm{PK} / \mathrm{PD}$. Experimental considerations are discussed as well as recommendations for understanding the potential impact of AAG on PK through drug discovery and early development.
\end{abstract}

KEY WORDS alpha- I-acid glycoprotein · fraction unbound · pharmacodynamics · pharmacokinetics · protein binding

Sherri A. Smith sas68@yahoo.com

Drug Metabolism, Pharmacokinetics and Bioanalytical, H3 Biomedicine, 300 Technology Square, Cambridge, Massachusetts 02139, USA

2 Nonclinical Development, Relay Therapeutics, 215 First Street, Cambridge, Massachusetts, USA

$\begin{array}{ll}\text { ABBREVIATIONS } & \\ \text { APP } & \text { Acute phase protein } \\ \text { AAG, AGP, ORM, orosomucoid } & \begin{array}{l}\text { Alpha-1-acid } \\ \text { glycoprotein }\end{array} \\ \text { AUC } & \text { Area under curve } \\ \text { CL } & \text { Clearance } \\ \text { DDI } & \text { Drug-drug interaction } \\ \text { DEHP } & \text { Diethylhexyl phthalate } \\ f_{u} & \text { Fraction unbound } \\ \text { HSA } & \text { Human serum } \\ & \text { albumin } \\ \text { IVIVE } & \text { In vitro in vivo } \\ & \text { extrapolation } \\ K_{D} & \text { Equilibrium } \\ & \text { dissociation constant } \\ \text { PD } & \text { Pharmacodynamics } \\ \text { PK } & \text { Pharmacokinetics } \\ V_{S S} & \text { Volume of distribution } \\ & \text { at steady-state }\end{array}$

\section{INTRODUCTION}

According to the free drug hypothesis only the unbound drug is available to act at physiological sites of action, whether it is the intended pharmacological target, or action at an undesired site with potential toxicological consequences. The importance of plasma protein binding primarily resides in its impact on pharmacokinetic properties such as clearance $(\mathrm{CL})$ and volume of distribution $\left(\mathrm{V}_{\mathrm{ss}}\right)$, with serum albumin, lipoproteins and alpha-1 acid glycoprotein (AAG) being the major proteins involved in sequestering drugs in plasma (1). AAG also known as orosomucoid (ORM), is a member of the acute phase protein (APP) family, first described in 1950 (2). It 
has a single polypeptide chain consisting of 183 amino acids with five glycan chains, accounting for $\sim 45 \%$ of its total molecular weight $(\sim 41-44 \mathrm{kDa})(3,4)$. AAG is formed primarily in the liver and circulates from 0.5 to $1.0 \mathrm{mg} / \mathrm{ml}$ in the plasma of healthy humans (3). Levels in healthy animals are generally lower compared to healthy humans (Table I). In most disease states including inflammation, infection, and cancer, AAG levels increase from 2 to 6 -fold in humans (3), and show a much broader fold of induction in animals from 2 to 20-fold depending on animal species and disease (Table I). While the biological role of AAG remains unclear, it has been demonstrated to regulate immunity and play a role in both pro- and anti-inflammatory response $(37,38)$. AAG has long been used as a clinical biomarker, and the potential to expand its

Table I AAG Levels in Plasma or Serum Across Species in Healthy and Disease State

\begin{tabular}{|c|c|c|c|c|c|}
\hline \multirow[t]{2}{*}{ Species/Strain or breed } & \multicolumn{3}{|c|}{ Mean or range (mg/ml) } & \multirow{2}{*}{$\begin{array}{l}\text { Acute phase response/ } \\
\text { Disease type }\end{array}$} & \multirow[t]{2}{*}{ Reference } \\
\hline & Healthy & Disease & Fold change disease/ Healthy & & \\
\hline Mouse/C57BL/6 & $0.09-0.11$ & $0.65-1.0$ & $7-9$ & Pulmonary Fibrosis & (5) \\
\hline Mouse/CDI & 0.096 & $\begin{array}{l}0.38 \\
1.58(1.35-1.81)\end{array}$ & $\begin{array}{l}4 \\
14-19\end{array}$ & $\begin{array}{l}\text { Cancer, tumor load: } \\
0.2-0.3 \text { g (8d post implant) } \\
0.8-1 \text { g ( I 5-20d post implant) }\end{array}$ & (6) \\
\hline Mouse/C57BL/6 & 0.1 & 2.0 & 20 & IL-I mediated induction & $(7)$ \\
\hline Mouse & 0.1 & 3.5 & $>20$ & Acute phase response & (8) \\
\hline Mouse/CDI \& NMRI & $0.99-1.1$ & & & & $(9)$ \\
\hline Rat/Dark Agouti & $0.20 \pm 0.01$ & $1.38 \pm 0.13$ & 7 & Phenobarbital induced ${ }^{b}$ & $(10)$ \\
\hline Rat/Sprague-Dawley & $0.30 \pm 0.04$ & $0.49 \pm 0.05$ & 2 & Phenobarbital induced ${ }^{b}$ & $(10)$ \\
\hline Rat/Sprague-Dawley & 0.13 & 0.25 & 2 & Stress & $(||)$ \\
\hline Rat/Lewis & 0.1 & $0.4-1.4$ & $4-14$ & Arthritis & $(12)$ \\
\hline Rat/Wistar & 0.1 & $\begin{array}{l}0.5 \\
1.0\end{array}$ & $\begin{array}{l}5 \\
10\end{array}$ & $\begin{array}{l}\text { Cirrhosis } \\
\text { Inflammation, LPS }\end{array}$ & $(13)$ \\
\hline Rat/Sprague-Dawley & $0.23-0.32$ & & & & (9) \\
\hline Rabbit/New Zealand White & $0.31-0.4 \mid$ & & & & (9) \\
\hline \multirow[t]{6}{*}{$\begin{array}{l}\text { Pig/Conventional } \\
\text { Crossbred }\end{array}$} & $\begin{array}{l}2.5 \\
1.5\end{array}$ & $\begin{array}{l}1.4 \\
1.1\end{array}$ & $\begin{array}{l}0.6 \\
0.7\end{array}$ & $\begin{array}{l}\text { Infection } \\
\text { Inflammation }\end{array}$ & $(14)$ \\
\hline & \multirow[t]{2}{*}{$0.34 \pm 0.08$} & $\begin{array}{l}0.1-1.0 \\
0.9-1.2\end{array}$ & $\begin{array}{l}\leq 3 \\
\leq 4\end{array}$ & $\begin{array}{l}\text { Arthritis } \\
\text { Hernia }\end{array}$ & \multirow[t]{2}{*}{$(15)$} \\
\hline & & $0.2-2.0$ & $\leq 6$ & Infection & \\
\hline & $0.3-0.6$ & $0.4-0.55$ & none & Inflammation, turpentine & $(16)$ \\
\hline & $0.3-0.6$ & $0.3-0.56$ & none & Inflammation, turpentine & $(17)$ \\
\hline & 1.08 & 0.98 & 0.9 & Inflammation, LPS & $(18)$ \\
\hline $\begin{array}{l}\text { Minipig/Ossabaw } \\
\text { Minipig/Gottingen }\end{array}$ & $\begin{array}{l}0.5 \\
0.3\end{array}$ & & & & $(14)$ \\
\hline \multirow[t]{2}{*}{ Minipig/Gottingen } & $\begin{array}{l}\sim 0.2 \\
0.3-0.4\end{array}$ & $\begin{array}{l}\sim 0.2 \\
\sim 0.9(0.6-1.5)\end{array}$ & $\begin{array}{l}\text { none } \\
2\end{array}$ & $\begin{array}{l}\text { Inflammation, LPSc } \\
\text { Obesity, High Fat Diet }\end{array}$ & \multirow[t]{2}{*}{$(19)$} \\
\hline & $0.3-0.4$ & $\sim 1.0(0.6-1.6)$ & 2 & Mild Diabetes, High Fat Diet & \\
\hline \multirow[t]{7}{*}{ Cat/Domestic } & $0.27^{\mathrm{a}}$ & $0.83^{\mathrm{a}}$ & 3 & Cancer & $(20)$ \\
\hline & $0.1-0.48$ & $\geq 1.5$ & $3-15$ & Infection & $(2 \mid)$ \\
\hline & \multirow[t]{2}{*}{0.23} & $\begin{array}{l}0.51 \\
1.12\end{array}$ & $\begin{array}{l}2 \\
5\end{array}$ & $\begin{array}{l}\text { Cancer } \\
\text { Infection, Coronavirus }\end{array}$ & \multirow[t]{2}{*}{$(22)$} \\
\hline & & 3.82 & 17 & Infection, Peritonitis & \\
\hline & $0.24 \pm 0.01$ & $4.71 \pm 1.47$ & $6-19$ & Inflammation/Diseased & $(23)$ \\
\hline & $<0.56$ & $2.89(2.04-14)$ & $>3-25$ & Infection & $(24)$ \\
\hline & $0.27-0.38$ & & & & (9) \\
\hline \multirow[t]{6}{*}{ Dog/Beagle } & $0.32(0.04-0.96)$ & $1.21-1.36$ & $1-34$ & Infection & (25) \\
\hline & 0.37 & 1.63 & 4 & Inflammation & $(26)$ \\
\hline & $0.25(0.17-0.33)$ & $0.83(0.5-1.3)$ & $2-7$ & Infection & $(27)$ \\
\hline & 0.47 & 2.85 & 6 & Inflammation & $(28)$ \\
\hline & 0.50 & 1.94 & 4 & Infection & (29) \\
\hline & $0.37-0.60$ & & & & (9) \\
\hline \multirow[t]{2}{*}{ Monkey/Cynomolgus } & \multirow[t]{2}{*}{0.11} & $1.85-2.67$ & $16-24$ & Inflammation & \multirow{2}{*}{$\begin{array}{l}\text { (30) } \\
\text { d }\end{array}$} \\
\hline & & & $5-10$ & Infection & \\
\hline Human & $0.67(0.45-1.12)$ & $\begin{array}{l}2.20 \pm 0.62 \\
\quad(1.03-3.15) \\
1.43 \pm 0.65 \\
(0.71-2.27)\end{array}$ & $2-3$ & $\begin{array}{l}\text { Cancer } \\
\text { Infection }\end{array}$ & $(3 \mid)$ \\
\hline
\end{tabular}


Table I (continued)

\begin{tabular}{|c|c|c|c|c|c|}
\hline \multirow[t]{2}{*}{ Species/Strain or breed } & \multicolumn{3}{|l|}{ Mean or range $(\mathrm{mg} / \mathrm{ml})$} & \multirow{2}{*}{$\begin{array}{l}\text { Acute phase response/ } \\
\text { Disease type }\end{array}$} & \multirow[t]{2}{*}{ Reference } \\
\hline & Healthy & Disease & Fold change disease/ Healthy & & \\
\hline & \multirow{4}{*}{$\begin{array}{l}0.46 \pm 0.17 \\
\sim 0.75\end{array}$} & $1.06 \pm 0.56$ & \multirow[t]{4}{*}{2} & Pulmonary Fibrosis & \multirow{4}{*}{$\begin{array}{l}\text { (5) } \\
(33)\end{array}$} \\
\hline & & $\begin{array}{l}\sim 0.9 \\
\sim 0.6\end{array}$ & & $\begin{array}{l}\text { Renal Failure } \\
\text { Cirrhosis }\end{array}$ & \\
\hline & & $\sim 1.1$ & & Chronic Uremia & \\
\hline & & $\sim 1.5$ & & After Hemodialysis & \\
\hline & \multirow[t]{2}{*}{$0.52 \pm 0.24$ (I-2 months) } & $\begin{array}{l}0.08-3.3 \text { (0-1 month) } \\
0.18-2.96(0-1 \text { month })\end{array}$ & \multirow[t]{2}{*}{$0.2-7$} & $\begin{array}{l}\text { Infection - Bacterial } \\
\text { Infection-Viral/Parasitological }\end{array}$ & (34) \\
\hline & & $0.36-1.8$ & & Cancer & (35) \\
\hline & $0.77 \pm 0.15(0.36-1.46)$ & & & & (36) \\
\hline & $0.5-1.0$ & $\leq 3.0$ & $3-6$ & Inflammation, infection, cancer & (3) \\
\hline
\end{tabular}

a Median value

${ }^{\mathrm{b}}$ Independent of inflammation pathway

c LPS Lipopolysaccharide (bacterial infection, acute inflammatory stimulus)

${ }^{d}$ Life Diagnostics, Inc., indicated on package insert

application for disease diagnosis, prognosis, and characterization has grown given the recent advances in proteomics and high resolution mass spectrometry (39-42).

While AAG represents a relatively small portion $(\sim 1-3 \%)$ of the total plasma proteins, compared to $\sim 60 \%$ composition of albumin, it can play a significant role in drug binding and pharmacokinetics (PK) (43). AAG is considered a high affinity/low capacity plasma protein, whereas albumin is considered low affinity/high capacity. AAG is a highly acidic protein with a very low isoelectric point $(\mathrm{pI})$ ranging from 2.8 to 3.8 (37). This property enables AAG to bind mainly basic drugs (i.e. lidocaine, propranolol, verapamil) but it may also bind to neutral lipophilic molecules (i.e. steroid hormones) and to acidic drugs (i.e. phenobarbital), whereas albumin is mostly implicated in binding to the latter charge type $(44,45)$. Most drugs bind to both plasma proteins with varying degrees of affinity. The extensive and variable sialylation of $\mathrm{AAG}$ is what drives the low and wide $\mathrm{pI}$ range, a property that can impact drug affinity, and ultimately PK (3). Since AAG levels increase in most disease states (46), drugs with a high affinity may demonstrate higher binding (lower fraction unbound, $\mathrm{f}_{\mathrm{u}}$ ) and altered PK properties (e.g. lower total CL), lower $\mathrm{V}_{\mathrm{ss}}$. Given the known species differences in AAG abundance and drug affinity there is a growing body of work where $\mathrm{PK}$ in preclinical species did not accurately predict PK in human, and several of these case studies are discussed herein. Incorporating the ontogeny of AAG may also enable more accurate predictions of PK in neonate and infant patients (47). We provide a rationale for testing the extent and affinity of drug binding to AAG and albumin in the drug discovery process to aid in prospective human PK prediction efforts (Fig. 1). Research is still lagging in the characterization of higher species AAG which could help better predict PK in human. Furthermore, there are experimental factors that are emerging as critical to the accurate determination of AAG-drug binding in vitro. These aspects are also discussed in this review.

\section{BIOCHEMISTRY OF AAG}

\section{Species}

Albumin, AAG, and lipoproteins are considered the most relevant plasma proteins in terms of drug binding (1). The range of albumin levels is slightly lower in animals compared to human. While levels of AAG are also relatively lower in most animals compared to human in the healthy state, levels are much more variable in the diseased setting as described below and in Table I. Human albumin and AAG levels in Table II provide units of $\mathrm{mg} / \mathrm{ml}$ and $\mu \mathrm{M}$ to serve as a quick reference when considering stoichiometry with drug concentrations, assuming a single drug binding site model. Generally, in rodents $(0.1-0.3 \mathrm{mg} / \mathrm{ml})$ and mini-pigs $(0.3-0.5 \mathrm{mg} / \mathrm{ml})$ AAG values are lower compared to human (Table I). An exception to this generalization was reported in mice, however no explanation was suggested by the authors (9). In dogs, AAG demonstrates highly variable levels $(0.04-1 \mathrm{mg} / \mathrm{ml})(25)$, though generally lower mean values $(0.25-0.5 \mathrm{mg} / \mathrm{ml})$ have been reported (26-28). There is little characterization of monkey AAG in the literature, though it has also been reported to be lower in cynomolgus monkey $(0.1 \mathrm{mg} / \mathrm{ml})$ compared to human (30). The conventional pig is the only species where AAG levels have been reported to be higher $(1.1-2.5 \mathrm{mg} / \mathrm{ml})(14,18) \mathrm{com}$ pared to human. However, this finding has not been consistently observed, lower AAG values of $0.24 \mathrm{mg} / \mathrm{ml}(16)$ and $0.34 \mathrm{mg} / \mathrm{ml}(15)$ have also been reported in the conventional pig. 
Fig. I Proposed flowchart to ascertain impact of AAG as a potential covariate for PK variability in early drug development.

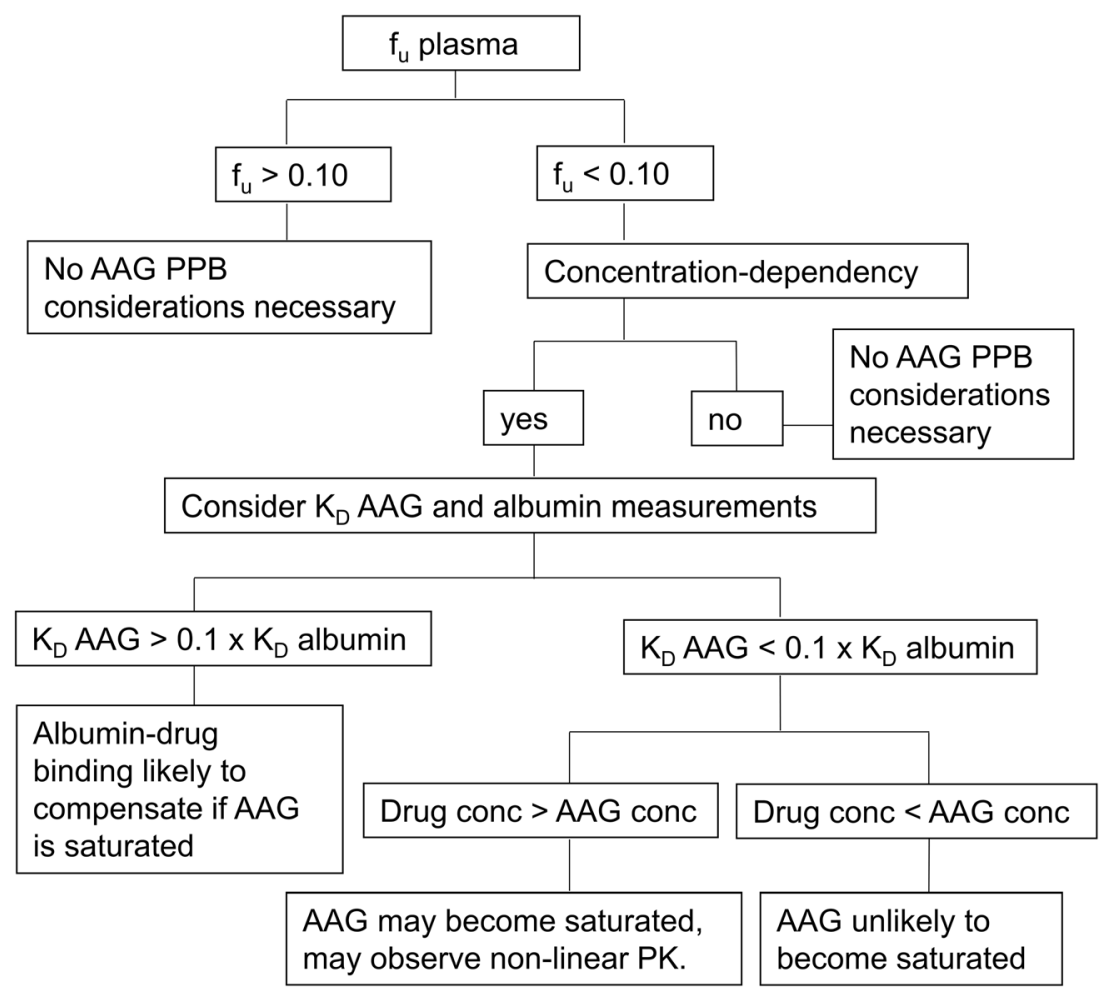

\section{Disease State}

In most species, AAG behaves as a positive acute phase protein (APP), increasing in response to stimuli, including infection, inflammation, and cancer (Table I). The acute phase response (APR) is considered part of the innate (non-specific) defense system that offers protection prior to the adaptive (specific) immune response. The magnitude of response can differ across species and disease setting. Minor, moderate, and major AAPs are characterized by increases in protein expression by $0.25-1,1-10$, and $>10$-fold, respectively. In mice AAG is considered a major positive APP as levels increase up to 20 -fold following stimuli $(7,8)$, whereas in human the response is relatively moderate with increases of $\sim 2-6$ fold $(3,31)$. In the domestic cat, AAG increases are moderate $(\sim 2-3$ fold) in the oncology setting, whereas a more robust response has been reported with infections (up to 17 -fold) (20-22).

Mixed responses have been reported in the conventional pig and the minipig. In the conventional pig, AAG has been

Table II Albumin and AAG Concentration Ranges in Plasma of Healthy Humans

\begin{tabular}{lllc}
\hline Protein & $\begin{array}{c}\text { MW } \\
\mathrm{kDa}\end{array}$ & \multicolumn{2}{l}{ Concentration } \\
\cline { 3 - 4 } & & $\mathrm{mg} / \mathrm{ml}$ & $\mu \mathrm{M}$ \\
\hline Albumin & 67 & $35-50$ & $500-750$ \\
AAG & 42 & $0.4-1.0$ & $9-24$ \\
\hline
\end{tabular}

shown to behave as both a negative APP with levels declining to $\sim 0.6-0.7$-fold normal values (14) and as a positive APP in response to infection and inflammation, with levels increasing 3-6-fold (15). In both conventional pigs (18) and minipigs $(16,48,49)$ there was no AAG response following acute stimuli (LPS or turpentine injection), despite increases in other APPs in the conventional pig (TNF $\alpha$ and IL-6) and in minipigs (C-reactive protein (CRP), serum amyloid A (SAA), haptoglobin (Hp), pig major acute phase protein (PMAP)). Christoffersen et al. (19) hypothesized the AAG response in the minipig may have different sensitivity in the acute versus chronic setting, an observation previously reported for other APPs (SAA and Hp) in cattle (49). In a chronic inflammatory setting, obese and mildly diabetic minipigs fed a high fat diet had elevated ( 2-fold) AAG levels (19). Changing housing conditions also caused up to a 2-fold increase in AAG in minipigs (as well as increases in GRP, SAA, Hp and PMAP), and it is unclear when levels return to baseline, a finding that should be considered in acclimation, experimental design and data interpretation (19). Neither the negative APP response nor LPS insensitivity of porcine AAG have been reported in any other species to date. However, it is not unprecedented for a given APP to behave differently across species. For example, while GRP and SAA are considered major positive APPs in human and pig, CRP and SAA are not affected in mice and rats, respectively. Another example of differential species response is with transferrin, which acts as a negative APP in human, and a positive APP in mice $(19,48)$. 


\section{Gender}

There have been mixed reports regarding gender differences in AAG levels. While there may be statistical differences, they are relatively modest compared to the differences observed in disease or developmental settings. Booker et al. (50) reported statistically significant differences in AAG levels between newborn human males $(0.42 \mathrm{mg} / \mathrm{ml})$ and females $(0.33 \mathrm{mg} / \mathrm{ml})$ (Table III). The opposite trend was observed in adult humans; AAG levels of 0.39 and $0.50 \mathrm{mg} / \mathrm{ml}$ in males and females, respectively (51). Similarly, Blain et al. (36) reported slightly lower levels in human males $(0.74 \mathrm{mg} / \mathrm{ml})$ compared to female $(0.84 \mathrm{mg} / \mathrm{ml})$. Female minipigs generally have slightly lower, though overlapping ranges, of AAG levels compared to males (19). No gender difference was observed in dog AAG levels $(0.32 \mathrm{mg} / \mathrm{ml})(25)$.

\section{Ontogeny}

AAG levels range from undetectable in the developing human fetus, to $0.1-0.2 \mathrm{mg} / \mathrm{ml}$ in cord blood $(47,51,53)$, up to $0.3 \mathrm{mg} / \mathrm{ml}$ at birth $(34,51,54-57)$, steadily increasing to 0.4 $0.7 \mathrm{mg} / \mathrm{ml}$ at $2-3$ months $(34,50,55)$, and achieving adult levels $(0.6-0.9 \mathrm{mg} / \mathrm{ml})$ by $10-12$ months of age $(33,34,58)$ (Table IV). Similarly, AAG is undetectable $(<0.04 \mathrm{mg} / \mathrm{ml})$ in the cord blood of dogs, thus significantly lower compared to adult dogs $(0.32 \mathrm{mg} / \mathrm{ml})$ (25). The opposite trend was observed in conventional pigs, with $12.7 \mathrm{mg} / \mathrm{ml}$ reported in the fetal pig, $14.3 \mathrm{mg} / \mathrm{ml}$ in 1 day newborns, $0.70 \mathrm{mg} / \mathrm{ml}$ in 4 week olds, and $0.24-0.34 \mathrm{mg} / \mathrm{ml}$ in adults $(15,16)$. Consistent with this pattern, Heegaard et al. (14) reported AAG levels of $6.6 \mathrm{mg} / \mathrm{ml}$ in newborn pigs (5-6 days old) that declined to $1.1 \mathrm{mg} / \mathrm{ml}$ in adults. AAG comprises about $50 \%$ of the total plasma proteins in the newborn pig, whereas only about $0.3 \%$ in the adult pig. This property has not been reported in mini-pigs or any other laboratory animal to date. Limited data have been published on fetal and neonatal plasma levels of AAG in other species. However, liver AAG levels in rat have also been shown to vary in development (60).

Table III AAG in Plasma or Serum Across Gender in Healthy Subjects

\begin{tabular}{llll}
\hline Species/Strain & \multicolumn{2}{l}{ Mean or range $(\mathrm{mg} / \mathrm{ml}) \pm$ Standard deviation } & \multirow{2}{*}{ Reference } \\
\cline { 2 - 3 } & Male & Female & \\
\hline Minipig/Gottingen & $0.29(0.23-0.42)$ & $0.41(0.32-0.56)$ & $(19)$ \\
Dog/Beagle & $0.32(0.04-0.96)$ & $0.32(0.05-0.83)$ & $(25)$ \\
Human & $0.74 \pm 0.17$ & $0.84 \pm 0.18$ & $(36)$ \\
& $0.39 \pm 0.08$ & $0.50 \pm 0.07$ & $(51)$ \\
& $0.42 \pm 0.17$ & $0.33 \pm 0.14$ & $(50)$ \\
& $0.62 \pm 0.12$ & $0.67 \pm 0.13$ & $(52)$ \\
\hline
\end{tabular}

\section{Pregnancy and Placental Transfer to Milk}

Pregnancy can also impact AAG levels. In human AAG levels are lower in the pregnant female and continue to decline throughout pregnancy until birth when they begin to climb back to pre-pregnancy values $(53,56,57)$. Wood and Wood (51) reported the same values in female non-pregnant healthy volunteers and pregnant women, however the study size was relatively small $(n=10)$. The opposite has been reported in the pregnant dog (25) and in rhesus monkey (59), with AAG levels about 2-fold and 4-fold higher in the pregnant animal, respectively.

Given the striking differences between fetal, newborn, and adult AAG levels, it may be important to understand placental transfer and the milk to plasma ratio $(\mathrm{M} / \mathrm{P})$ for drugs that bind to AAG. Fleishaker and McNamara (61) described a diffusional model to assess drug distribution in milk, showing that the in vitro drug binding to serum and milk protein reasonably predict $\mathrm{M} / \mathrm{P}$ drug ratio in vivo. The same authors tested the model in lactating rabbits using propranolol, a compound known to bind with high affinity to AAG. To mimic the disease setting, rabbits were dosed with bovine AAG and propranolol PK parameters were evaluated. The diffusional model was able to accurately predict the decrease in propranolol M/P from 2.13 to 1.23 before and after AAG administration. Importantly, a roughly proportional reduction in total plasma CL $(35 \%)$ counteracted the decrease in $\mathrm{f}_{\mathrm{u}}(22 \%)$, maintaining consistent $\mathrm{CL}_{\mathrm{u}}$ rate and total drug levels in milk.

To improve the prediction of $f_{u}$ in human infants McNamara and Alcorn (47) considered the ratio of AAG and albumin in cord blood of newborns and adult blood. The corresponding ratios for AAG and albumin employed were $0.38(0.24 \mathrm{mg} / \mathrm{ml}$ cord divided by $0.60 \mathrm{mg} / \mathrm{ml}$ adult $)$ and $0.81(36 \mathrm{mg} / \mathrm{ml}$ cord divided by $45 \mathrm{mg} / \mathrm{ml}$ adult). Prediction of $\mathrm{f}_{\mathrm{u}}$ in newborns was better for drugs that predominantly bind to albumin. The average predicted and observed ratios (newborn/adult), of $\mathrm{f}_{\mathrm{u}}$ were 1.20 and 1.38 , respectively, for drugs that predominantly bind to albumin $(n=28$ drugs in study set). The average predicted and observed ratios (newborn/adult), of $\mathrm{f}_{\mathrm{u}}$ were 1.61 and 2.50, respectively, for drugs that predominantly bind to AAG $(n=11$ drugs in study set). For the majority of drugs, the $\mathrm{f}_{\mathrm{u}}$ in newborns was under-predicted, 10/11 and 22/28 drugs that predominantly bind to AAG and albumin, respectively. Possible explanations for the disparity suggested by the authors include changes in drugligand affinity associated with age as well as increased free fatty acids and bilirubin in the newborn that can contribute to decreased drug binding. In addition, the under prediction may be due to inaccurate (falsely high) AAG and albumin newborn levels employed in the model. While AAG levels are generally more variable (higher dynamic range) compared to albumin, this alone cannot explain the trend in under prediction. 
Table IV Ontogeny and Impact of Pregnancy on AAG Protein Levels in Plasma or Serum

Species/Strain $\quad$ AAG mean or range $(\mathrm{mg} / \mathrm{ml}) \pm$ Standard deviation / Age or pregnancy status

Minipig/Gottingen
Minipig/Gottingen
Minipig/Ossabaw
Pig/Conventional crossbred
(Landrace Yorkshire)
Pig/Conventional crossbred
(Duroc Yorkshire Landrace)
Pig/Conventional crossbred
(Landrace White)

12.7

Dog/Beagle

Monkey/Rhesus

Human

$0.15 \pm 0.05 /$ cord

$<0.04 /$ cord
Reference

\begin{tabular}{lll}
\hline Fetus/Age Newborn/Age $\quad$ Adult/Age or pregnancy status
\end{tabular}

$0.34(0.25-0.53) / 6$ weeks $0.41(0.34-0.47) / 16$ weeks

$0.29(0.23-0.4 I) / 40-48$ weeks

$0.33(0.26-0.38) / 24$ weeks

$0.3 / 14-16$ months

$0.5 / 41-47$ months

0.6/8-9 months

|. |/26-3| days

$0.34 \pm 0.08 / 5-10$ months

$14.3 \pm 2.4 / 1$ days

$1.3 \pm 0.5 / 2$ weeks

$0.32(0.04-0.96) /$ male

0.32(0.05-0.83)/female

$0.63(0.25-1.0) /$ pregnant female

0.43-0.52/pregnancy 13-18 weeks

0.70 pregnancy 19 weeks

0.90/pregnancy 21 weeks

I.35/pregnancy 22 weeks

I.90/pregnancy 24 weeks

| .55-1.70/postpartem I-3 days

$0.14 \pm 0.20 /$ cord neonate

BLQ-0.15/12-23 weeks

0.06-0.33/27-34 weeks

0.08-0.4I/35-4I weeks

$0.05(0.02-0.2) / 19-34$ weeks

$0.24 /$ cord neonate

$0.1-0.3 /$ neonate

$0.34 \pm 0.15 / 30-36$ weeks

$0.46 \pm 0.19 / 1-12$ months

$0.66 \pm 0.28 / 1-5$ years

$0.63 \pm 0.16 / 12-18$ years

$0.13-0.20 /$ birth

$0.52 \pm 0.24 / 1-2$ months

$0.58 \pm 0.25 / 2-3$ months

$0.82 \pm 0.20 / 10$ months

$0.42 \pm 0.17 / 7$ weeks male

$0.33 \pm 0.14 / 10$ weeks female

0.25

$0.65 \pm 0.13 /$ pregnancy trimester |

$0.51 \pm 0.24$ /pregnancy trimester 2

$0.44 \pm 0.12$ /pregnancy trimester 3

$0.89 \pm 0.20$ /postpartum mother

$0.64 \pm 0.10 /$ non-pregnant female

0.50-1.05/pregnant female 12-23 weeks

0.38-0.99/pregnant female 27-34 weeks 0.29-0.88/pregnant female 35-4I weeks

$0.7(0.45-0.9)$ /non-pregnant female $0.55(0.35-0.8) /$ pregnant female $0.08(0.01-0.1)$ /amniotic fluid

0.60

0.7-2.5/postpartum mother

$0.94 \pm 0.22 / 2$ years

$0.84 \pm 0.18 / 3-4$ years

$0.88 \pm 0.21 / 5-9$ years

0.7

$0.50 \pm 0.07 /$ pregnant female

$0.50 \pm 0.07 /$ non-pregnant female

$0.28^{\mathrm{a}}(0.13-0.56)^{\mathrm{b}} / \mathrm{birth}$ $0.48^{\mathrm{a}}(0.31-0.93)^{\mathrm{b}} / \mathrm{I}$ month $0.39 \pm 0.08 /$ male

$0.83^{\mathrm{a}}(0.52-1.26)^{\mathrm{b}}$

)

$B Q L$, below limit of quantitation

a $50^{\text {th }}$ percentile values

${ }^{b} 5^{\text {th }}, 95$ th percentile values

$0.67^{\mathrm{a}}(0.41-0.97)^{\mathrm{b}} / 3$ months

$0.70^{\mathrm{a}}(0.43-1.49)^{\mathrm{b}} / 6$ months 


\section{STRUCTURE AND GENETICS OF HUMAN AAG}

Three genes (AAG-A, AAG-B, and AAG-B'), located on chromosome 9, encode human AAG (hAAG) (37). AAG-A encodes ORM1 and is expressed in the liver at $>100$-fold that of AAG-B and AAG-B'. AAG-B and AAG-B' are identical in structure, differ from AAG-A by 22 amino acids, and encode ORM2 (62). AAG shares significant homology with human immunoglobulin $\mathrm{G}(\mathrm{IgG})$ and the epidermal growth factor (EGF)-binding domain of the EGF receptor $(63,64)$.

AAG-A (ORMl) is polymorphic with three closely related genetic variants: $\mathrm{F} 1, \mathrm{~F} 2$, and $\mathrm{S}$, differing by $<5$ amino acid residues, and generally referred to as $\mathrm{F} 1 * \mathrm{~S}$ in Table $\mathrm{V}(65,66)$. AAG-B and AAG-B' (ORM2) encode the genetic variant A. Most individuals possess a mixture of these variants (67). F1 + $\mathrm{S}+\mathrm{A}$ is the most common phenotype (50\%), followed by $\mathrm{F} 1+\mathrm{A}(35 \%)$ and $\mathrm{S}+\mathrm{A}(15 \%)$. The molar ratio of $\mathrm{F} 1 * \mathrm{~S}$ to $\mathrm{A}$ is $\sim 2-3: 1$ in healthy individuals (67). The ratio can increase up to $8: 1$ in the disease setting since the $\mathrm{F} 1 * \mathrm{~S}$ variant is inducible (68). No gender related differences have been observed in expression of these variant forms (32). X-ray crystallography showed two common binding pocket lobes between the $\mathrm{F} 1 * \mathrm{~S}$ and $\mathrm{A}$ variants, while the $\mathrm{F} 1 * \mathrm{~S}$ variant possesses a unique third lobe making it more promiscuous for drug binding $(69,70)$. Drug binding properties have been shown to differ amongst these variants (71). For example, the basic drug imipramine was shown to bind more strongly to A variant, whereas warfarin more strongly to the $\mathrm{F} 1$ and $\mathrm{S}$ variants. For most drugs, binding to genetic variants has not been well characterized since protein binding studies are routinely conducted on a pooled supply of healthy human plasma or in the whole plasma of individual subjects/patients.

Proteins routinely undergo post-translational modifications that can impact physiological function and half-life $\left(t_{1 / 2}\right)$. Glycosylation, the addition of oligosaccharide chains (glycans) is one of the most abundant post-translational modifications, with an incidence of $\sim 50 \%$ in eukaryotic proteins (72). AAPs are particularly susceptible to glycosylation. Glycosyltransferases and glycosidases are responsible for building the precursors to glycans, a process highly vulnerable to changes in disease state
(73). Oligosaccharyltransferases then transfer glycans to the polypeptide chain at asparagine (N-linked) or serine/threonine (O-linked) residues, the former of which exhibit a common pentasaccharide core. The glycan bonds occur in either $\alpha$ or $\beta$ configuration allowing for more structural diversity. The antiinflammatory and immunomodulatory properties are directly impacted by glycan composition which, in turn, changes throughout the various stages of inflammation.

The heavily sialylated glycans make AAG one of the most acidic plasma proteins. There is a high level of heterogeneity resulting in a very low but wide $\mathrm{pI}$ ranging from 2.8 to 3.8 which in turn can impact drug binding and $\mathrm{AAG}_{\mathrm{t}_{1 / 2}}$ (37). Desialylation can result in an increase in $\mathrm{pI}$ range from 4.2 to 4.7 (74,75). Human AAG contains 5 N-linked glycans of the polypeptide backbone, each of which can form a variety of bi, tri, or tetra-branches all potentially further expressing sialic acid moieties (65). Despite thousands of potentially unique glycan combinations associated with AAG, only about 12 20 glycan combinations are observed in the plasma of healthy humans $(37,76)$. However, in the disease state many more glycan modifications have been detected under the regulation of inflammatory cytokines, tumor necrosis factor $(\mathrm{TNF} \alpha)$, interleukin-1 (IL-1) and IL-6 and its utility as a biomarker will be described later (76). AAG offers two drug binding sites for basic drugs, one for acid drugs (44), and up to 7 for steroids (45). Drug binding to AAG is reportedly mediated predominantly via hydrophobic interaction with some data suggesting potential for electrostatic interaction. Evidence to support the latter includes the observation of stereoselective binding in propranolol isomers (77). Desialylation and lower plasma $\mathrm{pH}$ have been shown to decrease drug binding to AAG $(78,79)$. Propranolol binding was reduced and progesterone binding unchanged with desialylated AAG.

Homologous AAG genes have been observed across mammals including rodents, cats, dogs, pigs, monkeys and humans (Table VI). Mouse, rat, rabbit, and pig AAG genes share $\sim 44 \%, 59 \%, 70 \%$ and $70 \%$ homology, respectively, with human AAG $(37,80)$. While there are three human AAG genes, there is only one gene reported in rat and two to three in mouse depending on strain or source. Despite the presence of multiple
Table V Genetic Variants of Human AAG

\begin{tabular}{|c|c|c|c|c|c|c|c|}
\hline \multirow[t]{2}{*}{ Gene $^{a}$} & \multirow[t]{2}{*}{$\operatorname{Protein}^{\mathrm{a}}$} & \multirow[t]{2}{*}{$\begin{array}{l}\text { Collective } \\
\text { variant }\end{array}$} & \multirow[t]{2}{*}{$\begin{array}{l}\text { Individual } \\
\text { variant }\end{array}$} & \multirow[t]{2}{*}{$\begin{array}{l}\text { Binding pocket } \\
\text { lobes }\end{array}$} & \multirow[t]{2}{*}{$\begin{array}{l}\text { Drug binding } \\
\text { selectivity }\end{array}$} & \multicolumn{2}{|c|}{$\begin{array}{l}\text { Variant molar ratio } \\
(\mathrm{F} \mid * \mathrm{~S} / \mathrm{A})\end{array}$} \\
\hline & & & & & & Healthy & Disease \\
\hline ORMI & AAG-A & $\mathrm{FI} * \mathrm{~S}$ & $\begin{array}{l}\mathrm{Fl} \\
\mathrm{F} 2 \\
\mathrm{~S}\end{array}$ & I, II, III & lower & $2-3$ & up to 8 \\
\hline ORM2 & $\begin{array}{l}\text { AAG-B } \\
\text { AAG-B' }\end{array}$ & A & $\begin{array}{l}A \\
A\end{array}$ & I, II & higher & I & 1 \\
\hline
\end{tabular}

References $(65,66)$

${ }^{a}$ Gene and protein nomenclature used interchangeably in literature 
Table VI AAG Characterization and Homology Across Species

\begin{tabular}{|c|c|c|c|c|c|c|c|c|c|}
\hline Species & Genes & Amino acids & N-linked glycans & $\begin{array}{l}\text { MW } \\
\mathrm{kDa}\end{array}$ & Disulfide bridges & Isoelectic point & Binding sites & $\begin{array}{l}\text { \% Homology } \\
\text { to human }\end{array}$ & Reference \\
\hline Mouse & & & & 43 & & 2.7 & & & (43) \\
\hline Mouse & 3 & & & 44 & & & & 44 & (80) \\
\hline Mouse & 2 & 187 & $5-6$ & 44 & & & & & $(81)$ \\
\hline Mouse & 3 & 189 & & $40-46$ & & & & 47 & a \\
\hline Rat & I & 187 & 6 & $40-44$ & 1 & & & 59 & $(37,82)$ \\
\hline Rat & I & & & & & & & & $(60)$ \\
\hline Rabbit & & 194 & & & & & & 70 & (83) \\
\hline Pig & I & 183 & 5 & 43 & 2 & $3.1-3.5$ & & & $(15)$ \\
\hline Pig & I & & 5 & $\begin{array}{l}43 \\
40\end{array}$ & 2 & $\begin{array}{l}3.6-4.3 \\
4.3-4.5\end{array}$ & & 70 & $(14)$ \\
\hline Pig & & & 5 & & & & & 70 & (84) \\
\hline Cow & & & & & & & Basic, Steroid & & (4) \\
\hline Dog & & & & & & & Basic, Steroid & & (4) \\
\hline Dog & 1 & & & 44 & & $3.5-3.8$ & & & (85) \\
\hline Human & 3 & & & & & $3.7-3.7$ & & & $(85)$ \\
\hline Human & 3 & 183 & 5 & $4 \mid-44$ & 2 & & Acid, Basic Steroid & & $(4,37)$ \\
\hline Human & & & & & & $2.8-3.8$ & & & $(66)$ \\
\hline
\end{tabular}

${ }^{\text {a Rndsystems.com }}$

genes, only one gene is associated with the positive APP $(86,87)$. AAG is comprised of 183 amino acid residues in human and 183-194 in animals. There are 5-6 asparagine (N)-linked glycans in human and rodents, most of which are highly conserved at positions 15, 38, 54, 75, and 85 in humans (88) and 16, 58, 75 , and 86 in rodents (81). Two disulfide bridges have been described in human and pig AAG, with only one in rat. Various binding sites have been characterized across species; in human acidic, basic, and steroid binding sites have been reported, whereas cows and dogs lack the acidic binding site (4).

\section{REGULATION AND ENDOGENOUS FUNCTION OF AAG}

AAG belongs to a family of APPs mainly generated in liver parenchymal cells at elevated levels within 12-24 h of injury (i.e. infection, inflammation, burns, cancer). APPs by definition are proteins that change in response to injury by $>25 \%$ in plasma (89). Examples of positive APPs include ceruloplasmin, AAG, and serum amyloid A (SAA), all increasing levels in humans by about 50\%, 3-fold, and > 1000-fold, respectively, in the diseased state (90). Negative APPs include albumin, transferrin, and insulin-like growth factor I, which modestly decline in plasma in the diseased state. AAG is a member of lipocalins, a superfamily of extra-cellular transporters that bind and transport small hydrophobic endogenous and exogenous chemicals. Upregulation of APPs enhances local inflammation by aiding in recognition of microbes, directing leukocytes, and increasing blood flow to the site of insult while minimizing inflammatory responses elsewhere (91). The rapid and high magnitude of response, as well as the short $t_{1 / 2}$, are properties characteristic of APPs and hypothesized to be key elements in innate immunity. Homeostasis is kept in check with redundancy such that a given APP may impact multiple pathways while multiple APPs may provide overlapping biological function. The inflammatory cytokines, TNF $\alpha$, IL-1 and IL-6, have been shown to regulate AAG, in addition to the other APPs including C-reactive protein (CRP), haptoglobin (Hp), SAA and hemopexin (92).

The function of AAG is still poorly understood, however, as part of a cytokine mediated feedback mechanism it has been implicated in both anti- and pro-inflammatory modulation $(37,38)$. Monocyte activation and induction of T-cell proliferation (93) as well as activation of TNF $\alpha$, IL-1 and IL-6 secretion (94-96) have been associated with the pro-inflammatory role of AAG. Su et al. (97) proposed a positive feedback mechanism of APPs whereby inflammation is amplified in response to TNF $\alpha$-mediated synthesis of AAG-stimulated monocytes and vice-versa. The anti-inflammatory role of AAG has also been reported. AAG inhibits neutrophil chemotactic response associated with stimulation of $\mathcal{N}$-Formylmethionyl-leucyl-phenylalanine (fMLP) and the inflammatory peptide complement component C5a $(98,99)$. AAG was shown to modulate release of free radicals regardless of treatment time, whether AAG was introduced prior to or post neutrophil activation (100). Multiple in vivo septic shock models in rodents have demonstrated the protective effect of AAG when dosed prophylactically to animals challenged by $\mathrm{TNF} \alpha$ or endotoxin (101).

The role of AAG in angiogenesis was studied using an ex vivo rat model (102). Following aortic excision, macrophages respond by rapidly (within minutes) increasing TNF $\alpha$ 
levels, peaking at $24 \mathrm{~h}$, and remaining elevated throughout angiogenesis. TNF $\alpha$ guides overexpression of AAG within $24 \mathrm{~h}$, with levels peaking after 2-3 days and sharply declining thereafter. As with inflammation, AAG (and TNF $\alpha$ ) has both pro- and anti-angiogenic effects depending on the context. Early in the angiogenesis process, AAG plays an inhibitory role via modulation of mitogen-activated protein kinases, whereas later in the process AAG promotes angiogenesis via vascular endothelial growth factor regulation.

\section{IMPACT OF DISEASE STATE ON AAG PROPERTIES AND UTILITY AS A BIOMARKER}

As an APP, levels of AAG typically increase within $24 \mathrm{~h}$ of injury and begin to decline several days post amelioration. Increased AAG levels have been reported in the serum of breast, lung, and ovarian cancer patients (103). In a study comparing AAG levels in lung cancer patients versus individuals with no known cancers, results showed 89\% sensitivity and 85\% specificity and AAG levels correlated with relapse-free survival (104). In the case of hepatocellular carcinoma (HCG), diagnosis can be challenging due to other liver conditions (i.e. cirrhosis) presenting similar abnormalities, however increased AAG levels are more pronounced with HCG providing a potential basis to differentiate these diseases (105). The proportion of breast cancer patients with increased AAG levels increases with disease progression, for example $25 \%$ and $81 \%$ of stage II and IV patients respectively, had elevated levels compared to $12 \%$ in healthy donors $(106,107)$.

In most disease states, AAG is modified both quantitatively as described above, as well as qualitatively, a phenomenon described by Alminquist and Lausing (39) after comparing serum glycoproteins of cancer patients versus healthy donors. Relative to the associated polypeptide backbone, the heterogeneity in glycan composition and structure make it a good system for characterization and correlation with disease state (73). Some commonly exploited glycoproteins used in clinical cancer biomarker tests include carcinoembryonic antigen (CEA), cancer antigen 125 (CA-125), CA-19-9, and prostate-specific antigen (PSA), for the diagnosis of colorectal, ovarian, pancreatic and prostate cancers, respectively. Technological advances in mass spectrometry and proteomics have led to an improved understanding of glycan structure and function. Glycans are relatively more abundant compared with their associated proteins, often times multiple copies per glycoprotein, as is the case for AAG known to have 5-6 associated glycans depending on species (Table VI). Not only are they associated with the cancerous tissue but they can also be detected in serum, making its use as a biomarker more feasible in the clinical setting. In addition, the same modified glycan may be associated with more than one glycoprotein affording multiple opportunities/patterns for detection.
Modifications of the glycans associated with these biomarkers are relatively more specific and selective than the epitope itself, allowing for more accurate means for distinguishing healthy versus diseased tissue, and disease progression (40). For example, testing serum levels of modified glycans associated with PSA enable the distinction between benign prostatic hypertrophy and cancerous prostate (41). In breast cancer, the serum glycosylation pattern not only distinguishes healthy from diseased tissue but also differentiates between malignant and non-malignant tumors and disease stage (73). In inflammatory diseases including rheumatoid arthritis and asthma, AAG glycans are more branched compared to healthy subjects (42). Patients suffering from acute inflammation, infection, burns, and tissue damage all showed an asialylated carbohydrate-deficient variant of AAG (37).

Human AAG $t_{1 / 2}$ is relatively short, $\sim 2-5$ days $(108,109)$, compared to albumin, 14-21 days (110). AAG turnover is dependent on sialic acid residues and terminal galactose groups. McCurdy (111) studied the impact of glycosylation on in vivo CL of human derived AAG in rabbit following intravenous injection. The terminal $t_{1 / 2}$ of native human AAG was $58 \mathrm{~h}$ (consistent with the $\mathrm{t}^{1 / 2}$ value of $69 \mathrm{~h}$ reported by Regoeczi et al. (112). Altered/reduced or absence of glycosylation lowered the $\mathrm{t}^{1 / 2}$ to $50 \mathrm{~h}$ and $42 \mathrm{~h}$, respectively. CL of native AAG was $2.2 \mathrm{ml} / \mathrm{h} / \mathrm{kg}$, whereas much higher values were observed for AAG forms with altered $(11 \mathrm{ml} / \mathrm{h} / \mathrm{kg})$ or absent glycosylation $(100 \mathrm{ml} / \mathrm{h} / \mathrm{kg})$. The steady-state volume of distribution $\left(\mathrm{V}_{\mathrm{ss}}\right)$ was $160 \mathrm{ml} / \mathrm{kg}$ for native $\mathrm{AAG}$, whereas much higher values were observed with altered $(550 \mathrm{ml} / \mathrm{kg}$ ) or absent glycosylation $(2000 \mathrm{ml} / \mathrm{kg})$. The absence, reduction or alteration of N-linked glycosylation resulted in a marked increase $(>10$-fold) in renal elimination compared to native AAG. These studies support that the dispositional properties of AAG are dependent on disease state since the biochemistry of AAG is altered with disease as described earlier. Therefore, if a given drug binds to AAG to a high extent, it is possible underlying differences in the PK of the drug between healthy and diseased populations may be attributable to AAG.

\section{IMPACT OF PLASMA PROTEIN BINDING ON PHARMACOKINETICS}

Drug binding to plasma, tissue(s) and intended target are critical parameters to predict PK and pharmacodynamics (PD). However, optimizing protein binding to plasma in the drug discovery setting is scientifically unsound (113,114). Nearly $30 \%$ of the 260 FDA approved drugs prior to 2003 are classified as highly bound $\left(>95 \%\right.$ or $\left.\mathrm{f}_{\mathrm{u}}<0.05\right)$, and this trend has increased in recent years with $45 \%$ of new drugs classified as highly bound, $24 \%$ of which have $\mathrm{f}_{\mathrm{u}}<0.01$ (115). While the free drug hypothesis describes that the free concentration 
drives activity as it can cross cellular membranes to reach its target, the focus should be to optimize $\mathrm{CL}_{\mathrm{u}}$ and permeability.

As described above, albumin, AAG, and lipoproteins are considered the most important plasma proteins involved with drug binding. While albumin has a higher drug capacity due to its relative abundance in plasma, AAG levels are lower and with high affinity drugs saturation may occur. The saturation of AAG may or may not be buffered by albumin depending on the drug binding affinity for albumin. Plasma protein levels can change with disease state, a decrease in albumin and an increase in AAG are generally observed, which may impact protein binding and PK. Both albumin and AAG levels are significantly lower in the newborn, with newborn:adult ratios of about 0.81 and 0.38 , respectively (47), a factor that should be considered when predicting $\mathrm{PK}$ in the very young pediatric population.

A proposed flowchart to ascertain the impact of AAG as a potential covariate for $\mathrm{PK}$ variability early in drug development is shown in Fig. 1. Routine screening in human and laboratory animal species at a single low concentration $(1-2 \mu \mathrm{M})$ is typically performed in early drug discovery as PK data in preclinical species is acquired. As a program advances towards development candidate selection with preliminary projections of human PK and dose, there is value in assessing concentration dependency and the identity of the major plasma proteins involved in drug binding. If the extent of binding is high $(>90 \%$ bound) under single concentration assay conditions, further characterization of the binding constants for AAG and albumin is warranted particularly if human free fraction is lower relative to animals or if concentration dependency is observed. If there is high affinity to human AAG it may be worthwhile to assess $\mathrm{K}_{\mathrm{D}}$ in other species to build additional confidence in human PK predictions.

\section{CONSIDERATIONS FOR PLASMA PROTEIN BINDING ASSAYS}

Multiple routine in vitro analytical procedures exist to assess the extent and affinity of drug binding to proteins. A recently published industry white paper (Di et al., 2017) provides a comprehensive review of commonly used protein-binding practices, challenges, and recommendations (116). The intention in this section of the manuscript is to suggest use of control compounds and to describe a source for erroneous fraction unbound values that has been overlooked.

\section{Control Compounds}

As with any assay it is good practice to include control compounds that are assessed along with test compounds to ensure a properly functioning assay. If data for control compounds are not available for a given assay/species one can still monitor the value for the control over time to ensure its consistency. When conducting definitive assays the use of multiple control compounds is advised since multiple factors can influence binding and some are compound specific. Literature values for propranolol and warfarin are summarized across species in Table VII. The intent here is to provide references for acceptable free fraction values for control compounds across species. Propranolol was selected because it has moderately high binding to human plasma proteins, however the affinity is higher for AAG relative to albumin by approximately two orders of magnitude (125), therefore, propranolol can serve as a control for compounds that preferentially bind to AAG. The reported propranolol $f_{u}$ values range from 0.10 to 0.29 in human plasma, a 3-fold difference, and outside what is typically deemed normal assay variability. The acceptable assay $f_{u}$ value for propranolol should be within 0.10 to 0.20 in healthy human plasma. Warfarin was selected because it is highly bound to both AAG and albumin (126, GE life sciences application note $29263246 \mathrm{AA}$ ). It is helpful to include a highly bound control compound since they generally require longer incubation time to achieve equilibrium. While the reported warfarin $f_{u}$ values range from 0.005 to 0.022 in human plasma, more than a 4-fold difference, the absolute difference is low. The majority of references indicate a narrower range, therefore the acceptable assay $f_{u}$ value for warfarin should be within 0.005 to 0.015 , a range similar to that reported in the recently published white paper (116). It is not advised to select a compound with moderate or low protein binding to serve as a control because the $f_{u}$ values are generally more variable.

\section{Effect of Plasticizers on Drug-Protein Binding}

Based on recent studies $(127,128)$ it is possible the large range in human $f_{u}$ values is due to the blood collection and storage procedure. In the clinical setting, $\mathrm{f}_{\mathrm{u}}$ is typically measured in the plasma or serum of patients from blood collected in vacutainers. The collection procedure and storage of blood can have a significant impact on protein binding results. It has long been reported that plasticizers can disrupt the binding of drugs to AAG (129-131). For example, the plasticizer Tris (2-butoxyethyl) phosphate (TBEP), used to soften rubber stoppers in vacutainers, was shown to disrupt AAG binding to the basic drugs lidocaine and quinidine (132). Polyvinyl chloride (PVC) bags containing the plasticizer diethylhexyl phthalate (DEHP) are routinely used in blood collection. Butler et al. (127) reported an average of a two-fold increase in $f_{u}$ for drugs known to bind to AAG when blood was collected in these PVC bags versus blood collected in vacutainers. More recently, experiments were conducted to show the correlation between 
Table VII Reported Plasma or Serum Protein Binding Values for Propranolol and Warfarin

\begin{tabular}{|c|c|c|c|c|}
\hline \multirow[t]{2}{*}{ Species } & \multirow[t]{2}{*}{ Drug $\mu \mathrm{M}$} & \multicolumn{2}{|c|}{$f_{u}$ mean or range } & \multirow{2}{*}{$\begin{array}{l}\text { Reference, meeting } \\
\text { or website }\end{array}$} \\
\hline & & Propranolol & Warfarin & \\
\hline \multirow[t]{3}{*}{ Mouse } & I & & $0.10-0.11$ & $(1 \mid 7)$ \\
\hline & 10 & 0.17 & 0.07 & a \\
\hline & 10 & 0.15 & 0.06 & b \\
\hline \multirow[t]{8}{*}{ Rat } & h & & $0.010-0.018$ & $(117)$ \\
\hline & 0.04 & 0.08 & & $(1 \mid 8)$ \\
\hline & 1 & 0.21 & 0.005 & c \\
\hline & I & & $0.003-0.004$ & d \\
\hline & I & 0.28 & 0.005 & $(119)$ \\
\hline & 5 & 0.06 & & e \\
\hline & 10 & 0.19 & 0.01 & a \\
\hline & 10 & 0.15 & 0.007 & b \\
\hline \multirow[t]{3}{*}{ Rabbit } & h & & $0.042-0.052$ & $(117)$ \\
\hline & 0.04 & 0.35 & & $(118)$ \\
\hline & $0.22-2.5$ & 0.34 & & $(120)$ \\
\hline \multirow[t]{6}{*}{ Dog } & h & & 0.040 & $(117)$ \\
\hline & 0.04 & 0.10 & & $(1 \mid 8)$ \\
\hline & । & 0.27 & 0.038 & c \\
\hline & । & 0.20 & 0.033 & $(119)$ \\
\hline & 10 & 0.23 & 0.04 & a \\
\hline & 10 & 0.20 & 0.046 & b \\
\hline Guinea pig & 10 & 0.17 & 0.02 & a \\
\hline Minipig & 10 & 0.18 & 0.03 & a \\
\hline \multirow[t]{3}{*}{ Monkey } & I & 0.21 & & $(|2|)$ \\
\hline & । & 0.21 & 0.005 & $(119)$ \\
\hline & 10 & 0.20 & 0.01 & c \\
\hline \multirow[t]{14}{*}{ Human } & h & & $0.012-0.022$ & $(117)$ \\
\hline & 0.04 & 0.10 & & $(\mid 18)$ \\
\hline & hi & 0.10 & & f \\
\hline & hi & & 0.01 & g \\
\hline & I & 0.21 & 0.006 & $(119)$ \\
\hline & 1 & 0.14 & & $(121)$ \\
\hline & I & 0.13 & 0.011 & c \\
\hline & I & 0.16 & $0.005-0.006$ & d \\
\hline & I & 0.29 & & $(122)$ \\
\hline & 1 & 0.13 & & $(123)$ \\
\hline & $1-3^{i}$ & & 0.005 & $(124)$ \\
\hline & 5 & 0.27 & & e \\
\hline & 10 & 0.12 & $<0.01$ & a \\
\hline & 10 & 0.19 & 0.007 & b \\
\hline
\end{tabular}

${ }^{a}$ BD Biosciences brochure (now Corning), In vitro ADME discovery screening services, plasma protein binding using rapid equilibrium dialysis

${ }^{b}$ BD Biosciences (now Corning) Application Note 474, 2009, Shanler M, Mason A, Crocker R, Vardaro R, Crespi C, Stresser D, Validation of an automated high throughput plasma protein binding assay

c www.noabbiodiscoveries.com website

${ }^{d}$ Pierce Biotechnololgy, Inc., www.piercenet.com, Li S, Xiong B, Huang T, Li L, Donovan J, Lee F, Yu S, Miwa G, and Yang $\mathrm{H}$, Validation of a novel rapid equilibrium dialysis (RED) device for high throughput plasma protein binding determination, 2006

e Waters Corporation Application Note 720002610, Shave D and Alden P, Determination of protein binding by UPLC/MS/MS

fWyeth Package Insert, 2912389

${ }^{g}$ Bristol-Myers Squibb Package Insert, 3022954

${ }^{\mathrm{h}}$ drug concentration not indicated

'Values reported from ex vivo plasma samples 
DEHP levels and change in $\mathrm{f}_{\mathrm{u}}$ with drugs that bind to AAG (128). When blood was immediately transferred from Terumo ${ }^{\circledR}$ bags to vacutainers the DEHP levels were low (1$10 \mu \mathrm{M}$ ) but steadily increased with storage after 7 days (up to $300 \mu \mathrm{M})$ and 28 days (300-1000 $\mu \mathrm{M})$. DEHP can easily leach into the contents of bags since it is not chemically bound to the PVC. As expected, $f_{u}$ was higher (2-5-fold) with drugs known to bind to AAG when tested using plasma containing high levels of DEHP. The shift in $f_{u}$ was significantly reduced, though not eliminated, when the blood was immediately transferred to vacutainers.

Results generated using blood products collected/stored in plasticizer containing bags should be interpreted with caution as the $\mathrm{f}_{\mathrm{u}}$ values may over-estimate true in viwo values. In most instances when protein binding is measured clinically, vacutainers (no/minimal DEHP exposure) are used since small $(<10 \mathrm{ml})$ blood volumes are collected. This is in contrast to the relatively larger volumes (up to $350 \mathrm{ml}$ ) collected in bags for donation and/or non-clinical research purposes. It should be noted that the blood from animals is typically collected in smaller vessels not containing DEHP, therefore the over-estimation of $f_{u}$ is less likely to occur in animal blood. Studies may be warranted to assess effects on drug binding with other commercially available vacutainers as a precaution. Despite what has been reported in the literature for decades, bags containing plasticizers known to disrupt AAG-drug binding continue to be widely used for blood collection with the intended use in both research and in the clinical setting. DEHP is essential in maintaining the shelf life of blood products up to 42 days as it protects the membrane of the red blood cell (133). Transfusion recipients routinely receive blood that has been collected and stored in these bags. Clinical effects with regard to drug displacement have not been reported. Other blood collection bags have been developed though it is unclear if they have an effect on AAG-drug binding.

\section{EXAMPLES WHERE AAG BINDING INFLUENCES PHARMACOKINETICS}

Multiple classes of drugs have been reported to bind to AAG. Examples of the relationship between AAG binding and lipid solubility and/or electrostatic interactions have been reported for benzodiazepines, phenothiazine neuroleptics, beta blockers, anthracycline derivatives, antihistamines, and analgesics $(3,126)$. Here we focus on several well-studied examples where the drug-AAG binding affected PK and/or PD in the clinical oncology setting.

\section{Vismodegib}

Vismodegib was approved for the treatment of metastatic basal cell carcinoma by the Food and Drug Administration (FDA) in 2012. PK characteristics exhibited in the phase I clinical trial were unexpected based on preclinical allometric scaling. Following a single oral dose, exposure was higher than predicted with a very low apparent CL and a long $\mathrm{t}_{1 / 2}$ of about 10-12 days (134). Cross species in vitro data showed high plasma protein binding ( $\geq 95 \%$ bound) and low metabolic turnover in hepatocytes of all species except monkey, which agreed well with in vivo CL values (135).

Mechanistic PK modeling was employed to explain the roles of plasma protein binding, solubility-limited absorption, and low metabolic CL in contributing to the unusual clinical PK properties (136). In vitro studies revealed far lower vismodegib solubility, $0.0001 \mathrm{mg} / \mathrm{ml}$ at higher $\mathrm{pH}$ range $6.5-7.4$, compared to $\sim 1.0 \mathrm{mg} / \mathrm{ml}$ at $\mathrm{pH} 0.1$ (136). The impact of solubility was manifested in saturation of oral absorption. There was no increase in mean steady-state concentration $\left(\mathrm{C}_{\mathrm{ss}}\right), 22.6,21.3$ and $22.0 \mu \mathrm{M}$, with increase in oral dose from 150 to 270 and $540 \mathrm{mg}$, respectively (137). The free fraction of vismodegib remained constant at $0.5 \pm 0.1 \%$ across all dose groups (137). However, in a separate study, a 2.6-fold increase in free fraction of vismodegib was reported between a single $150 \mathrm{mg}$ dose $(0.25 \pm 0.14 \%)$ versus repeat daily $150 \mathrm{mg}$ doses $(0.65 \pm 2.9 \%)(138)$.

Vismodegib plasma protein binding properties were further characterized by isothermal titration calorimetry (ITC) and surface plasmon resonance (SPR) with both procedures showing higher vismodegib-AAG affinity to the human isoform relative to the rat isoform (139). By ITC the $\mathrm{K}_{\mathrm{D}}$ values of vismodegib-AAG were 1.1 and $118 \mu \mathrm{M}$ in human and rat, respectively. By SPR the $K_{D}$ values of vismodegib-AAG were $13 \mu \mathrm{M}$ and not detectable in human and rat, respectively, whereas the $\mathrm{K}_{\mathrm{D}}$ values for vismodegib-albumin were similar in human and rat (120 and $140 \mu \mathrm{M}$, respectively). In vitro experiments showed a negative correlation between AAG concentration and target engagement, whereby supplementing physiologically relevant concentrations of AAG resulted in a dampening of Hh signaling via GLII-luciferase reporter assay (139). There was a high correlation $\left(\mathrm{r}^{2}=0.73\right.$, slope 0.48$)$ between $\mathrm{AAG}$ and total vismodegib $\mathrm{C}_{\mathrm{sS}}$ in plasma samples from cancer patients, suggesting the role of plasma protein binding in vismodegib drug disposition (136). Perhaps even more compelling was the intra-patient parallel changes in total vismodegib concentrations with changes in AAG. No correlation was found with albumin levels and vismodegib concentrations (139). Saturation of AAG has been proposed to be a key determinant in the non-linear PK of vismodegib given that AAG is a high affinity-low capacity protein and near stoichiometric levels of vismodegib and AAG are reported (138). Despite the high affinity and resultant low free fraction, there remains sufficient unbound vismodegib available to interact with target to demonstrate pharmacological effect.

In order to understand the mechanism(s) of non-linear PK, healthy human subjects received either a single oral dose or 7 daily oral doses of $150 \mathrm{mg}$ vismodegib, followed 
by an IV microtracer dose of $10 \mu \mathrm{g}\left[{ }^{14} \mathrm{C}\right]$-vismodegib $2 \mathrm{~h}$ post first or last (day 7) oral dose (140). AAG levels were within close range in the two dose groups to eliminate need for correction. $\mathrm{CL}$ and $\mathrm{V}_{\mathrm{ss}}$ values after a single IV dose were $43.4 \mathrm{ml} / \mathrm{h}$ and $16.4 \mathrm{l}$, roughly $10-65$-fold lower (depending on number of species employed in model) and 3-fold lower, respectively, compared to preclinical allometric scaling predictions (135). Relative to day $1, \mathrm{CL}$ and $\mathrm{V}_{\mathrm{ss}}$ increased $81 \%$ and $63 \%$, respectively on day 7 , while $\mathrm{t}_{1 / 2}$ remained unchanged at $\sim 10-11$ days. Mean free fraction increased 2.4-fold after 7 days oral dosing $(0.79 \pm 0.23 \%)$ compared to a single dose $(0.33 \pm 0.12 \%)$, a finding consistent with the observations previously described (138). Correcting for protein binding of vismodegib, the unbound CL and $\mathrm{V}_{\mathrm{ss}}$ values were relatively similar on day 1 and 7 . Absolute bioavailability was $31.8 \%$ following a single oral dose and declined to $7.4 \%$ after 7 days of repeat dosing, a finding attributed to slow absorption and limited intestinal solubility (140).

Given the non-linear PK with long $t_{1 / 2}$, a phase Ib clinical study was conducted to determine if vismodegib steady-state concentrations could be maintained with less frequent dosing (138). Three oral dosing schedules were evaluated: $150 \mathrm{mg}$ once daily (QD), once weekly (QW) or three times per week (TIW), all after having received a loading dose of vismodegib (150 mg QD, 11 days). After steady-state was achieved for the alternate dose schedules, vismodegib levels declined in the QW and TIW groups relative to $\mathrm{QD}$, however the decline in unbound vismodegib $(50 \%$ and $80 \%$, respectively) was greater than the decline in total vismodegib ( $24 \%$ and $45 \%$, respectively). Only the QD dose schedule maintained unbound vismodegib concentrations sufficient to achieve target pathway inhibition $\left(\mathrm{IC}_{95}\right)$ of glioma-associated oncogene (Gli1) previously described (141), therefore the recommended dose and schedule was maintained at $150 \mathrm{mg}$ QD.

One additional point of consideration is the discrepancy between in vitro and ex vivo free fraction values reported for vismodegib in human plasma, $\sim 3-4 \%$ and $<0.25-0.79 \%$, respectively $(135,137,138,140)$. This discrepancy may be attributed to the collection and storage of blood products as described herein and in recent publications $(127,128)$. Free fraction values increased sharply for AAG-binding drugs when human blood was exposed to plasticizer DEHP; for example, vismodegib free fraction increased from $0.2 \%$ when collected in vacutainer (no/minimal plasticizer), to $0.4 \%$ and $1.4 \%$ when collected and stored in Terumo ${ }^{\circledR}$ bags containing plasticizer for $<1$ and 7 days, respectively. Additionally, vismodegib free fraction increased from 0.3 to $2.9 \%$ when human plasma was spiked with $800 \mu \mathrm{M}$ plasticizer, a concentration one could expect to measure in blood after several weeks storage in Terumo ${ }^{\circledR}$ or similar bags.

\section{UCN-OI}

UCN-01 (7-hydroxystaurosporine) is a small molecule protein kinase inhibitor. Single agent clinical trials were initiated for multiple oncological indications in the late 1990s, followed by combination studies with other anti-cancer agents. The PK parameters in preclinical species (mouse, rat and dog) ranged as follows: moderate to high CL roughly 30 to $80 \%$ hepatic blood flow, high $\mathrm{V}_{\mathrm{ss}} 6$ to $17 \mathrm{l} / \mathrm{kg}$, and moderate $\mathrm{t}_{1 / 2}$ from 3 to $12 \mathrm{~h}$ (142). Clinical PK were not predicted by allometry and exhibited low $\mathrm{CL}(17 \mathrm{ml} / \mathrm{h})$, low $\mathrm{V}_{\mathrm{ss}}(12 \mathrm{l})$ and very long $\mathrm{t}_{1 / 2}$ $(>200 \mathrm{~h})(143)$. While UCN-01 $(1 \mu \mathrm{g} / \mathrm{ml})$ is considered highly bound to plasma proteins in preclinical species with free fraction ranging from 0.5 to $1.8 \%$, the free fraction was substantially lower in human plasma at $<0.02 \%(144)$. UCN-01 free fraction was $<0.02 \%$ or $6.2 \%$ when incubated with physiologically relevant levels of hAAG $(1 \mathrm{mg} / \mathrm{ml})$ or albumin $(40 \mathrm{mg} / \mathrm{ml}$ ), respectively, showing the preferential binding to AAG. In vitro studies showed marked increase in UCN-01 free fraction with increases in concentration approaching stoichiometric levels of AAG (145). The association constant $\left(\mathrm{K}_{\mathbf{a}}\right)$ was $799 \times 10^{6} \mathrm{l} / \mathrm{mol}$ in hAAG (roughly equivalent to $\mathrm{K}_{\mathrm{D}}$ of $1.25 \mathrm{nM}$ ), whereas in $\operatorname{dog}$ the $\mathrm{K}_{\mathrm{a}}$ was $\sim 60$-fold lower at $13.2 \times 10^{6} 1 / \mathrm{mol}(145,146)$. Sparreboom et al., further characterized the role of AAG in the PK of UCN-01 (147). With an increase in dose ranging from 3.6 to $53 \mathrm{mg} / \mathrm{m}^{2} /$ day IV infusion over $72 \mathrm{~h}$, there was an increase in CL, $4.13 \mathrm{ml} / \mathrm{h}$ to $24.1 \mathrm{ml} / \mathrm{h}$, respectively, a linear increase in $\mathrm{V}_{\mathrm{ss}}, 0.113 \mathrm{l}$ to 0.2761 , respectively, and less than proportional (3.5-fold) increase in $\mathrm{AUC}_{\infty}$, (area under the curve extrapolated to infinity) 7460 to $26,140 \mathrm{mg} * \mathrm{~h} / \mathrm{l}$. CL trended $\left(\mathrm{r}^{2}=0.264\right)$ with pre-dose AAG levels, despite a relatively small data set $(n=39)$. It is proposed the increase in CL in humans is due, at least in part, to the increase in free fraction once AAG becomes saturated. CL in dogs had demonstrated no dependence on dose from 0.81 to $6.48 \mathrm{mg} / \mathrm{kg}(142,148)$, a finding consistent with the notable difference in UCN-01-AAG $\mathrm{K}_{\mathrm{D}}$ in human versus dog.

The $\mathrm{K}_{\mathrm{D}}$ of hAAG-UCN-01 is roughly 4 orders of magnitude lower compared to $\mathrm{K}_{\mathrm{D}}$ hAAG-vismodegib (139). In addition, UCN-01 does not appear to bind significantly to albumin given the comparable $\mathrm{K}_{\mathrm{D}}$ values of $\mathrm{UCN}-01$ to $\mathrm{AAG}$ vs human plasma, 799 vs $802 \times 10^{6} \mathrm{l} / \mathrm{mol}$, respectively (145). Saturation of AAG and the differential affinity to AAG and albumin are likely to contribute to the non-linear PK of UCN01. As with vismodegib the hAAG-UNC-01 $\mathrm{K}_{\mathrm{D}}$ differed considerably from that of the preclinical species leading to poor predictive accuracy with allometric methods. UCN-01 has a slow dissociation rate which may reduce $\mathrm{V}_{\mathrm{ss}}$, further hindering free drug from target interaction (139), in contrast to the preclinical observations of high $\mathrm{V}_{\mathrm{ss}}$, high tumor:plasma ratios, and decline in tumor volume (142). UCN-01 has not advanced in the clinic due to unpredictable PK and off-target kinase inhibition (146). 


\section{Imatinib}

Imatinib is a selective inhibitor of Bcr-Abl, platelet-derived growth factor receptors, and c-KIT receptor tyrosine kinases (149). Approval was granted for the treatment of chronic myelogenous leukemia and gastrointestinal stromal tumors by the FDA in 2001 and 2002. Imatinib-AAG binding is concentration-dependent with a reported $\mathrm{K}_{\mathrm{a}}$ of $1.7 \times 10^{6} \mathrm{l} /$ mol, roughly equivalent to $\mathrm{K}_{\mathrm{D}}$ of $0.6 \mu \mathrm{M}$, while imatinibalbumin binding is considerably weaker with a $\mathrm{K}_{\mathrm{a}}$ of $3.0 \times$ $10^{4} \mathrm{l} / \mathrm{mol}$, roughly equivalent to $\mathrm{K}_{\mathrm{D}}$ of $33 \mu \mathrm{M}(139,150)$. Adding to the complexity is the differential binding of imatinib to various human AAG isoforms, the $\mathrm{K}_{\mathrm{a}}$ reported above is for the F1-S variant, whereas binding was much weaker for the A variant (unpublished data) (151). Separately incubating $24 \mu \mathrm{M}$ of the AAG variants F1-S and A with $5 \mu \mathrm{M}$ imatinib resulted in $6 \%$ and $18 \%$ free fraction, respectively.

Imatinib exhibits linear PK in patients (152) with low oral CL ranging from 8 to $12 \mathrm{l} / \mathrm{h}(150,153,154)$, long $\mathrm{t}_{1 / 2}$ of $18 \mathrm{~h}$ and high oral bioavailability $>90 \%$. A proportional increase in AUC is observed with oral doses from 25 to $1000 \mathrm{mg}$. PK parameters are similar between single and repeat doses, showing 1.5- to 2.5-fold accumulation at steady-state. Correlations between imatinib $\mathrm{PK}$ and $\mathrm{ABCB} 1$ genotype, body weight and AAG levels was shown in patients $(150,155)$. Despite linear PK in total imatinib, a non-linear relationship exists between free fraction and total imatinib concentrations in plasma as a result of high affinity to AAG and 55-fold weaker affinity to albumin (156). Elevated levels of AAG in patients have been linked with delayed or lack of response to imatinib treatment as well as potential resistance mechanism $(157,158)$. In a clinical study with CML patients, approximately half exhibited elevated AAG levels positively correlating with disease progression and white blood count. In the chronic, accelerated, and blast crisis phases of disease, 33, 83 and 75\% of these patients, respectively, were increasingly likely to have higher AAG levels.

The impact of the plasticizer DEHP on imatinib free fraction in human plasma was also assessed (128). Imatinib free fraction increased from $3.5 \%$ when collected in vacutainer (no/minimal plasticizer), to $4.9 \%$ and $14.7 \%$ when collected and stored in Terumo ${ }^{\circledR}$ bags containing plasticizer for $<1$ and 7 days, respectively. Additionally, imatinib free fraction increased from 3.5 to $15.3 \%$ when human plasma was spiked with $800 \mu \mathrm{M}$ plasticizer. The plasticizer-free free fraction values reported by Ingram et al. (128) are similar $(\sim 5 \%)$ to those reported in the package insert (Novartis Pharmaceuticals Corporation, Reference T2017-101).

\section{Pinometostat}

Pinometostat (EPZ-5676) is a first-in-class, small molecule inhibitor of DOT1L and was the first member of the novel histone methyltransferase inhibitor class to enter Phase 1 clinical trials in both adult and pediatric MLL-r leukemia patients. Consensus preclinical predictions across multiple diverse methods suggested pinometostat would be a moderate-to-high CL compound in human with estimates ranging from 8 to $18 \mathrm{ml} / \mathrm{min} / \mathrm{kg}$, and species-invariant time approaches showed cross-species congruence in time-concentration profile. However, during early development, the observed CL in human was shown to be markedly lower than that determined in preclinical species. The majority of interspecies scaling and allometric methods over-predicted human CL of pinometostat with fold errors ranging from 4 to 13 (159), characterized by 'vertical allometry'. The 3-5-fold difference in free fraction between rat and human provided the basis for the improved prediction using the free fraction corrected intercept (FCIM) method. The unambiguous species difference in $\mathrm{CL}$ was not related to qualitative differences in metabolic pathways or routes of elimination, but instead to cross-species differences in plasma protein binding. Concentration dependence in protein binding was observed in human plasma, over a relevant concentration range, which was less apparent in the preclinical species. This, along with in vitro kinetic determinations, suggested the saturable binding of pinometostat to AAG. The equilibrium dissociation constant $\left(\mathrm{K}_{\mathrm{D}}\right)$ for pinometostat binding to human AAG was measured as $0.24 \mu \mathrm{M}$ indicating a high affinity interaction. By comparison, prototypical AAG ligands such as dipyridamol, disopyramide and thioridazine have $\mathrm{K}_{\mathrm{D}}$ values of 15.5, 1.0 and $63 \mu \mathrm{M}$ respectively. Furthermore, there is the disproportionately higher expression of $\mathrm{AAG}$ in human plasma relative to preclinical species, which is likely a contributing factor alone, irrespective of potential speciesspecific differences in AAG affinity.

\section{CONCLUSIONS AND SUMMARY}

It has been suggested when the $\mathrm{K}_{\mathrm{D}}$ for a given drug-AAG binding is low, and more than a log order lower relative to the $\mathrm{K}_{\mathrm{D}}$ for albumin, the PK may exhibit non-linearity (136). If the drug also has a high affinity to albumin, a high capacity protein, fluctuations in free fraction will be minimal. If the drug has a low affinity to albumin, the non-linear effect may be exacerbated when drug levels are near stoichiometric with $\mathrm{AAG}$, since $\mathrm{AAG}$ is a low capacity protein and may become saturated. Given the known differences in abundance and homology across species for AAG, allometric scaling may not be suitable for human PK prediction when there are differences in $\mathrm{K}_{\mathrm{D}}$, something that can easily be measured in vitro now that AAG of preclinical species are commercially available, though still limited in supply. Monitoring AAG and/or free drug concentrations, as well as phenotyping the genetic 
variants of AAG in patients may be warranted in special circumstances to better understand PK and PD. In Fig. 1, we propose a flowchart for incorporation of protein binding assessment in drug research and development.

Investigations are ongoing to propose more reliable procedures for the collection and storage of blood for future use in drug free fraction measurements (personal communications with $\mathrm{Q}^{2}$ Solutions Holdings, LLC). Special consideration should be given to pregnancy and pediatric populations since AAG levels are substantially lower until about 10 months post-natal. PBPK models have shown predictive utility with incorporation of AAG and albumin levels and drug binding parameters. Quantitative and/or qualitative analysis of AAG may prove useful as a biomarker for disease diagnosis and prognosis, with the potential to serve as discerning criteria to improve likelihood of successful treatment. Since AAG behaves as a positive APR protein in most species (except pig), with levels increasing to varying extents in the disease setting, it may be helpful to consider when comparing PK in healthy versus diseased populations or in translating PK/PD relationships across species.

\section{COMPLIANCE WITH ETHICAL STANDARDS}

Conflict of Interest The authors declare that they have no conflict of interest.

Publisher's Note Springer Nature remains neutral with regard to jurisdictional claims in published maps and institutional affiliations.

\section{REFERENCES}

1. Mehvar R. Role of protein binding in pharmacokinetics. Am J Pharm Educ. 2005;69(5):1-8.

2. Schmid K. Preparation and properties of an acid glycoprotein prepared from human plasma.J Am Chem Soc. 1950;72(6):2816.

3. Kremer JMH, Wilting J, Janssen LHM. Drug binding to human alpha-1-acid glycoprotein in health and disease. Pharmacol Rev. 1988;40(1):1-47.

4. Matsumoto K, Sukimoto K, Nishi K, Maruyama T, Suenaga A, Otagiri M. Characterization of ligand binding sites on the alphalacid glycoprotein in humans, bovines and dogs. Drug Metab Pharmacokinet. 2002;17(4):300-6.

5. Azuma M, Nishioka Y, Aono Y, Inayama M, Makino H, Kishi J, et al. Role of $\alpha 1$-acid glycoprotein in therapeutic antifibrotic effects of imatinib with macrolides in mice. Am J Respir Crit Care Med. 2007;176:1243-50.

6. Gambacorti-Passerini C, Barni R, Le Coutre P, Zucchetti GC, Cleris L, Rossi F, et al. Role of $\alpha 1$ acid glycoprotein in the in vivo resistance of human BCR-ABL ${ }^{+}$leukemic cells to the Abl inhibitor STI57 1. J Natl Cancer Inst. 2000;92(20):1641-50.

7. Hochepied T, Van Molle W, Berger F, Baumann H, Libert C. Nonspecific resistance to a lethal gram-negative infection. J Biol Chem. 2000;275(20):14909.

8. Schreiber G, Tsykin A, Aldred AR, Thomas T, Fung W-P, Dickson PW, et al. The acute phase response in the rodent. Ann N Y Acad Sci. 1989;557:61-85.
9. Pahlman I, Gozzi P. Serum binding of tolterodine and its major metabolites in humans and several animal species. Biopharm Drug Dispos. 1999;20:91-9.

10. Chauvelot-Moachon L, Delers F, Pous F, Engler R, Tallet F, Giroud JP. Alpha-1-acid glycoprotein concentrations and protein binding of propranolol in Sprague-Dawley and Dark Agouti rat strains treated by phenobarbital. J Pharmacol Exp Ther. 1988;244(3): 1103-8.

11. Deak T, Meriwether JL, Fleshner M, Spencer RL, Abouhamze A, Moldawer LL, et al. Stress-induced acute phase response. Am J Phys. 1987;273(6):R1998-2003.

12. Stolina M, Schett G, Dwyer D, Vonderfecht S, Middleton S, Duryea $\mathrm{D}$, et al. RANKL inhibition by osteoprotegerin prevents bone loss without affecting local or systemic inflammation parameters in two rat arthritis models: comparison with anti-TNF $\alpha$ or anti-IL-1 therapies. Arthritis Res Ther. 2009;11(6):R187.

13. Nielsen SS, Grofte T, Tygstrup N, Vilstrup H. Synthesis of acute phase proteins in rats with cirrhosis exposed to lipopolysaccharide. Comp Hepatol. 2006;5(3):1-7.

14. Heegaard PMH, Miller I, Sorensen NS, Sorensen KE, Skovgaard K. Pig $\alpha 1$-acid glycoprotein: characterization and first description in any species as a negative acute phase protein. PLoS One. 2013;8(7):1-13.

15. Itoh H, Tamur K, Izumi M, Motoi Y, Kidoguchi K, Funayama Y. The influence of age and health status on the serum alpha-1-acid glycoprotein level of conventional and specific pathogen-free pigs. Can J Vet Res. 1992;57:74-8.

16. Lampreave F, Pinerio A. The major serum protein of fetal and newborn pigs: biochemical properties and identification as a fetal form of $\alpha 1$-acid glycoprotein. Int J BioChemiPhysics. 1984;16:4753.

17. Eckersall PD, Saini PK, McComb C. The acute phase response of acid soluble glycoprotein, alpha (1)-acid glycoprotein, ceruloplasmin, haptoglobin and C-reactive protein, in the pig. Vet Immunol Immunopathol. 1996;51:377-85.

18. Webel DM, Finck BN, Baker DH, Johnson RW. Time course of increased plasma cytokines, cortisol, and urea nitrogen in pigs following intraperitoneal injection of lipopolysaccharide. J Anim Sci. 1997;75:1514-20.

19. Christoffersen B, Jesen S, Ludvigsen T, Nilsson S, Grossi A, Heegaard P. Age- and sex-associated effects on acute-phase proteins in Gottingen minipigs. Comp Med. 2015;65(4):333-41.

20. Winkel WM, Pavan T, Wirthl V, Alves A, Lucas S. Serum $\alpha-1$ acid glycoprotein and serum amyloid A concentrations in cats receiving antineoplastic treatment for lymphoma. Am J Vet Res. 2015;76(11):983-8.

21. Duthie S, Eckersall PD, Addie DD, Lawrence CE, Jarrett O. Value of $\alpha 1$-acid glycoprotein in the diagnosis of feline infectious peritonitis. Vet Rec. 1997;141:299-303.

22. Paltrinieri S, Giordano A, Tranquillo V, Guazzetti S. Critical assessment of the diagnostic value of feline $\alpha 1$-acid glycoprotein for feline infectious peritonitis using the likelihood ratios approach. J Vet Diagn Investig. 2007;19:266-72.

23. Kajikawa T, Onish F, Tajima T, Suqii S. Changes in concentrations of serum amyloid A protein, a-1-acid glycoprotein, haptoglobin, and C-reactive protein in feline sera due to induced inflammation and surgery. Vet Immunol Immunopathol. 1999;68(1):91-8.

24. Giori L, Giordano A, Giudice C, Grieco V, Paltrinieri S. Performances of different diagnostic tests for feline infectious peritonitis in challenging clinical cases. J Small Anim Pract. 201 1;52: $152-7$.

25. Kuribayashi T, Shimizu M, Shimada T, Honjyo T, Yamamoto Y, Kuba K, et al. Alpha 1Acid glycoprotein (AAG) levels in healthy and pregnant beagle dogs. Exp Anim. 2003;52(5):377-81. 
26. Belpaire FM, Braeckman RA, Bogaert MG. Binding of oxprenolol and propranolol to serum, albumin and alpha 1-acid glycoprotein in man and other species. Biochem Pharmacol. 1984;13: 2056-9.

27. Rikihisa Y, Yamamoto S, Kwak I, Iqbal Z, Kociba G, Mott J, et al. C-reactive protein and $\alpha$-1-acid glycoprotein levels in dogs infected with Ehrlichia Canis. J Clin Microbiol. 1994;32(4):912-7.

28. Dello CP, Belpaire FM, Kint JA, Freyman NH. Dog alpha-1-acid glycoprotein: purification and biochemical characterization. J Pharmacol Methods. 1987; 18:335-45.

29. Hagman R. Serum a-1-acid glycoprotein concentrations in 26 dogs with pyometra. Vet Clin Pathol. 201 1;40(1):52-9.

30. Asano S, Okano A, Ozawa K, Nakahata T, Ishibashi T, Koike K, et al. In vivo effects of recombinant human interleukin-6 in primates: stimulated production of platelets. Blood. 1990;75:1602-5.

31. Paxton JW, Briant RH. Alpha 1-acid glycoprotein concentrations and propranolol binding in elderly patients with acute illness. $\mathrm{Br} \mathrm{J}$ Clin Pharmacol. 1984;18(5):806-10.

32. Duche JC, Herve F, Tillement JP. Study of the expression of the genetic variants of human alphal-acid glycoprotein in healthy subjects using isoelectric focusing and immunoblotting. J Chromatogr B Analyt Technol Biomed Life Sci. 1998;715(1): 103-9.

33. Pacifici GM, Viani A, Taddeucci-Brunelli G, Rizzo G, Carria M, Sculz HU. Effects of development, aging, and renal and hepatic insufficiency as well as hemodialysis on the plasma concentrations of albumin and alpha 1-acid glycoprotein: implications for binding of drugs. Ther Drug Monit. 1986;8(3):259-63.

34. Bienvenu J, Sann L, Bienvenu F, Lahet C, DivryJC, Bethenod M. Laser nephelometry of orosomucoid in serum of newborns: reference intervals and relation to bacterial infections. Clin Chem. 1981;27(5):721-6.

35. Gambacortti-Passerini C, Zucchetti M, Russo D, Frapolli R, Verga M, Bungaro $\mathrm{S}$, et al. $\alpha \mathrm{l}$ acid glycoprotein binds to imatinib (STI571) and substantially alters its pharmacokinetics in chronic myeloid leukemia patients. Clin Cancer Res. 2003;9:625-32.

36. Blain PG, Mucklow JC, Rawlins MD, Roberts DF, Routledge PA, Shand DG. Determinants of plasma alpha-1-acid glycoprotein (AAG) concentrations in health. Br J Clin Pharmacol. 1985;20: 500-2.

37. Fournier T, Medjoubi N, Porquet D. Alpha-1-acid glycoprotein. Biochim Biophys Acta. 2000;1482(1-2):157-71.

38. Logdberg L, Wester L. Immunocalins: a lipocalin subfamily that modulates immune and inflammatory responses. Biochim Biophys Acta. 2000;1482:284-97.

39. Alminquist PO, Lausing E. A study of serum glycoproteins in cancer. Scand J Clin Lab Invest. 1957;9(2):179-83.

40. Drake P, Cho W, Li B, Prakobphol A, Johanse E, Anderson N, et al. Sweetening the pot: adding glycosylation to the biomarker discovery equation. Clin Chem. 2010;56(2):223-36.

41. Ohyama C, Hosono M, Nitta K, Oh-eda M, Yoshikawa K, Habuchi $\mathrm{T}$, et al. Carbohydrate structure and differential binding of prostate specific antigen to Maackia amurensis lectin between prostate cancer and benign prostate hypertrophy. Glycobiology. 2004;14:671-9.

42. VanDen Heuvel MM, Poland DC, De Graaff CS, Hoefsmit EC, Postmus PE, Beelen RH, et al. The degree of branching of the glycans of alpha(1)-acid glycoprotein in asthma. A correlation with lung function and inflammatory parameters. Am J Respir Crit Care Med. 2000;161(6):1972-8.

43. Schmid K. $\alpha 1$-acid glycoprotein. In: Putnam FW, editor. The plasma proteins: structure, function and genetic control. New York: Academic; 1975. p. 183-92.

44. SchleyJ, Mueller-Oerlinghausen B. Investigation of the binding of various tricyclic neuroletpics and antidepressants to alpha 1-acid glycoprotein. J Pharm Pharmacol. 1986;38:102-6.
45. Kerkay J, Westphal U, Steroid-protein XIX. Complex formation between al-acid steroid hormones. Biochim Biophys Acta. 1968;170:324-33.

46. Wright JD, Boudinot FD, Ujhelyi MR. Measurement and analysis of unbound drug concentrations. Clin Pharmacokinet. 1996;30(6): 445-62.

47. McNamara PJ, Alcorn J. Protein binding predictions in infants. AAPS PharmSci. 2002;4(1):19-26.

48. Heegaard PMH, Bog-Hansen TC. Transferrin and a2macroglobulin-I are circulating acute phase reactants in the mouse. In: Bienvenu J, Grimaud JA, Laurent P, editors. Marker proteins in inflammation, vol. 3. New York: W.de Gruyter; 1986. p. 275-92.

49. Horadagoda NU, Knox KM, Gibbs HA, Reid SW, Horadagoda A, Edwards WE, et al. Acute phase proteins in cattle: discrimination between acute and chronic inflammation. Vet Rec. 1999;144(16):437-41.

50. Booker PD, Taylor C, Saba G. Perioperative changes in $\alpha_{1}$-acid glycoprotein concentrations in infants undergoing major surgery. Br J Anaesth. 1996;76:365-8.

51. Wood M, Wood AJ. Changes in plasma drug binding and alpha 1 -acid glycoprotein in mother and newborn infant. Clin Pharmacol Ther. 1981;29(4):522-6.

52. Routledge PA, Stargel WW, Kitchell BB, Barchowsky A, Shand DG. Sex-related differences in the plasma protein binding of lignoncaine and diazepam. Br J Clin Pharmacol. 1981;11:245-50.

53. Echizen H, Nakura M, Saotome T, Minoura S, Ishizaki T. Plasma protein binding of disopyramide in pregnant and postpartum women, and in neoates and their mothers. Br J Clin Pharmacol. 1990;29:423-30.

54. Herngren L, Ehrnebo M, Boreus LO. Drug binding to plasma proteins during human pregnancy and in the perinatal period, studies on cloxacillin and alprenolol. Dev Pharmacol Ther. 1983;6(2):110-24.

55. Kanakoudi F, Drossou V, Tzimouli V, Diamanti E, Konstantinidis T, Germenis A, et al. Serum concentrations of 10 acute-phase proteins in healthy term and preterm infants from birth to age 6 months. Clin Chem. 1995;41(4):605-8.

56. Krauer B, Dayer P, Anner R. Changes in serum albumin and alpha-1 acid glycoprotein concentrations during pregnancy: an analysis of fetal-maternal pairs. Br J Obstet Gynaecol. 1984;91(9):875-81.

57. Seta N, Tissot B, Forestier F, Feger J, Daffos F, Durand G. Changes in $\alpha_{1}$-acid glycoprotein serum concentrations and glycoforms in the developing human fetus. Clin Chim Acta. 1991;203(2-3):167-75.

58. Lerman J, Strong HA, LeDez KM, Swartz J, Rider MJ, Burrows FA. Effects of age on the serum concentration of $\alpha_{1}$-acid glycoprotein and the binding of lidocaine in pediatric. Clin Pharmacol Ther. 1989;46(2):219-25.

59. Golub MS, Kaaekuahiwi MA. Changes in plasma alpha 1-acid glycoprotein and albumin concentrations during late pregnancy in rhesus monkeys. Clin Chim Acta. 1997;262:29-37.

60. Thomas T, Fletcher S, Yeoh G. The expression of $\alpha$-1-acid glycoprotein mRNA during rat development. High levels of expression in the decidua. J Biol Chem. 1989;264(10):5784-90.

61. Fleishaker JC, McNamara PJ. Effect of altered serum protein binding on propranolol distribution into milk in the lactating rabbit. J Pharmacol Exp Ther. 1988;244(3):925-8.

62. Dente L, Pizza MG, Metspalu R, Cortese R. Structure and expression of the genes coding for human alpha 1-acid glycoprotein. EMBO J. 1977;6:2289-96.

63. Schmid K, Nimerg RB, Kimura A, Yamaguchi H, Binette JP. The carbohydrate units of human plasma alphal-acid glycoprotein. Biochim Biophys Acta. 1977;492(2):291-302. 
64. Toh H, Hayashida H, Kikuno R, Yasunaga T, Miyata T. Sequence similarity between EGF receptor and a l-acid glycoprotein. Nature. 1985;314:199-203.

65. Schmid K. Human plasma alpha 1-acid glycoprotein-biochemical properties, the amino acid sequence and the structure of the carbohydrate moiety, variants and polymorphism. Prog Clin Biol Res. 1989;300:7-22.

66. Taguchi K, Nishi K, Chuang VTG, Maruyama T, Otagiri M. Molecular aspects of human alpha-1 acid glycoprotein - structure and function. In: Veas F, editor. Acute phase proteins, regulation and function of acute phase proteins. New York: Curtin Research Publications; 2013. p. 139-62. https://doi.org/10.5772/56101.

67. Eap CB, Baumann P. The genetic polymorphism of human alpha 1-acid glycoprotein. Prog Clin Biol Res. 1989;300:111-2.

68. Budai L, Ozohanics O, Ludanyi K, Drahos L, Kremmer T, Krenyacz J, et al. Investigation of genetic variants of alpha-1 acid glycoprotein by ultra-performance liquid chromatography-mass spectrometry. Anal Bioanal Chem. 2009;393(3):991-8.

69. Nishi K, Ono T, Nakamura T, Fukunaga N, Izumi M, Watanabe $\mathrm{H}$, et al. Structural insights into differences in drug-binding selectivity between two forms of human alpha 1-acid glycoprotein genetic variants, the A and $\mathrm{F} 1 * \mathrm{~S}$ form. J Biol Chem. 201 1;286(16): 14427-34.

70. Schonfeld DL, Ravelli RB, Mueller U, Skerra A. The 1.8-A crystral structure of alpha 1-acid glycoprotein (Orosomucoid) solved by UV RIP reveals the broad drug-binding activity of this human plasma lipocalin. J Mol Biol. 2008;384(2):393-405.

71. Herve F, Gomas E, Duche JC, Tillemant JP. Evidence for differences in the binding of drugs to the two main genetic variants of human $\alpha 1$-acid glycoprotein. Br J Clin Pharmacol. 1993;36:2419.

72. Apweiler R, Hermajakob H, Sharon N. On the frequency of protein glycosylation, as deduced from analysis of the SWISSPROT database. Biochim Biophys Acta. 1999;1473(1):4-8.

73. Smith KD, Behan J, Matthews-Smith G, Magliocco AM. Alpha1-acid glycoprotein (AGP) as a potential biomarker for breast cancer. In: Veas F, editor. Acute phase proteins, regulation and functions of acute phase proteins, vol. 2012. New York: Curtin Research Publications; 2012. p. 201-22. https://doi.org/10. 5772/48177.

74. Eap CB, Cuendet C, Baumann P. Orosomucoid (alphal-acid glycoprotein) phenotyping by use of immobilized $\mathrm{pH}$ gradients with $8 \mathrm{M}$ urea and immunoblotting. A new variant encountered in immunoblotting. Hum Genet. 1988;80:183-5.

75. Iijima S, Shiba K, Kimura M, Nagai K, Iwai T. Changes of alphal-acid glycoprotein microheterogeneity in acute inflammation stages analyzed by isoelectric focusing using serum obtained postoperatively. Electrophoresis. 2000;21:753-9.

76. Van Dijk W, Havenaar E, Brinkman-van der Linken E. Alpha aacid glycoprotein (orosomucoid): pathophysiological changes in glycosylation in relation to its function. Glycoconj J. 1995;12: 227-33.

77. Gills AM, Yee YG, Kates RE. Binding of antiarrhythmic drugs to purified human al-acid glycoprotein. Biochem Pharmacol. 1985;34(24):4279-82.

78. Ponganis KV, Stanski DR. Factors affecting the measurement of lidocaine protein binding by equilibrium dialysis in human serum. J Pharm Sci. 1985;74:57-60.

79. Wong AKL, Hsia JC. In vitro binding of propranolol and progesterone to native and desialyated human orosomucoid. Can J Biochem Cell Biol. 1983;61:1114-6.

80. Cooper R, Papaconstantinou J. Evidence for the existence of multiple alpha 1-acid glycoprotein genes in the mouse. J Biol Chem. 1986;261:1849-53.

81. Lee SG, Chang GJ, Lee YM, Lei HY, Lai MGY, Chen DS. Molecular cloning of cDNAs corresponding to two genes of alpha 1-acid glycoprotein and characterization of two alleles of AGP-1 in the mouse. DNA. 1989;8:245-51.

82. Ricca GA, Hamilton RW, McLean JW, Conn A, Kalinyak JE, Taylor JM. Rat alpha 1-acid glycoprotein mRNA. Cloning of double-stranded cDNA and kinetics of induction of mRNA levels following acute inflammation. J Biol Clin. 1981;256:10362-8.

83. Ray BK, Ray A. Molecular cloning and nucleotide sequence of complimentary DNA encoding rabbit al-acid glycoprotein. Biochem Biophys Res Commun. 1991;178(2):507-13.

84. Stone RT, Maurer RA. Cloning and developmental regulation of alpha 1 acid glycoprotein in swine. Dev Genet. 1987;8:295-304.

85. Dello CP, Belpaire FM, De Rick A, Fraeyman NH. Influence of inflammation of serum concentration, molecular heterogeneity and drug binding properties of canine alpha-1-acid glycoprotein. J Vet Pharmacol Ther. 1988;11:71-6.

86. Carter KC, Post DJ, Papaconstantinou J. Differential expression of the mouse alpha 1-acid glycoprotein genes (AGP-1 and AGP-2) during inflammation and aging. Biochim Biophys Acta. 1991;1089:315-20.

87. Dente L, Ruther U, Tripodi M, Wager EF, Cortese R. Expression of human alpha-1-acid glycoprotein genes in cultured cells and in transgenic mice. Genes Dev. 1988;2:259-66.

88. Treuheit MJ, Costello CE, Halsall HB. Analysis of the five glycosylation sites of human $\alpha 1$-acid glycoprotein. Biochem J. 1992;283(1):105-12.

89. Morley J, Kushner I. Serum C-reactive protein levels in disease. Ann N Y Acad Sci. 1982;389:406-18.

90. Gabay C, Kushner I. Acute-phase proteins and other systemic responses to inflammation. N Engl J Med. 1999;340(6):448-54.

91. Janciauskiene S, Welte T, Mahadeva R. Acute phase proteins: structure and function relationship. In: Veas F, editor. Acute phase proteins. New York: Curtin Research Publications; 2011. p. 25-60. https://doi.org/10.5772/18121.

92. Kushner I, Mackiewiecz A. The acute-phase response: an overview. In: Mackiewicz A, Kushner I, Bauman H, editors. Acute phase proteins molecular biology, biochemistry and clinical applications. Boca Raton: CRC Press; 1993. p. 3-19.

93. Singh VK, Fudenberg HH. Lymphocyte stimulation in vitro by orosomucoid glycoprotein. Immunol Lett. 1986;14:9-13.

94. Boutten A, Dehoux M, Deschenes M, Rouzeau JD, Bories PN, Durand G. Alpha l-acid glycoprotein potentiates lipopolysaccharide-induced secretion of interleukin-1 beta, interleukin- 6 and tumor necrosis factor-alpha by human monocytes and alveolar and peritoneal macrophages. Eur J Immunol. 1992;22:2687-265.

95. DrenthJP, van der Meer JW, Kushner I. Unstimulated peripheral blood mononuclear cells from patients with the hyper-IgD syndrome produce cytokines capable of potent induction of Creactive protein and serum amyloid A in Hep3B cells. J Immunol. 1996;157:400-4.

96. Su SJ, Yeh TM. Effects of alpha 1-acid glycoprotein on tissue factor expression and tumor necrosis factor secretion in human monocytes. Immunopharmacology. 1996;34:139-45.

97. Su SJ, Yang BC, Wang YS, Yeh TM. Alpha 1-acid glycoproteininduced tumor necrosis factor-alpha secretion of human monocytes is enhanced by serum binding proteins and depends on protein tyrosine kinase activation. Immunopharmacology. 1999;41: 21-9.

98. Laine A, Leroy A, Hachulla E, Davril M, Dessaint JP. Comparison of the effects of purified human alpha 1-acid antichymotrypsin and alpha 1-protease inhibitor on NK cytotoxicity: only alpha 1-protease inhibitor inhibits natural killing. Clin Chim Acta. 1990;190:163-73.

99. Vasson MP, Baquet JC, Arveiller MR, Bargnoux PJ, Giroud JP, Raichvarg D. Serum and urinary alpha-1 acid glycoprotein in chronic renal failure. Nephron. 1993;65(2):299-303. 
100. Rinaldi M, Geciliani F, Lecchi C, Moroni P, Bannerman DD. Differential effects of al-acid glycoprotein on bovine neutrophil respiratory burst activity and IL-8 production. Vet Immunol Iummunopath. 2008;126:199-210.

101. Libert C, Brouckaert P, Fiers W. Protection by alpha 1-acid glycoprotein against tumor necrosis factor-induced lethality. J Exp Med. 1994;180:1571-5.

102. Ligresti G, Aplin A, Dunn B, Morishita A, Nicosia R. The acute phase reactant orosomucoid-1 is a bimodal regulator of angiogenesis with time- and context-dependent inhibitory and stimulatory properties. PLoS One. 2012;7(8):1-15.

103. Duche JC, Urien S, Simon N, Malaurie E, Monnet I, Barre J. Expression of the genetic variants of human alpha-1-acid glycoprotein in cancer. Clin Biochem. 2000;33(3):197-202.

104. Ganz PA, Baras M, Ma PY, Elashoff RM. Monitoring the therapy of lung cancer with alpha-1-acid glycoprotein. Cancer Res. 1984;44(11):5415-21.

105. Kang X, Sun L, Guo K, Shu H, Yao J, Qin X, et al. Serum protein biomarkers screening in HCC patients with liver cirrhosis by ICAT-LG-MS/MS. J Cancer Res Clin Oncol. 2010;136(8): $1151-9$.

106. Kailajarva M, Ahokoski O, Virtanen A, Salminen E, Irjala K. Early effects of adjuvant tamoxifen therapy on serum hormones, proteins and lipids. Anticancer Res. 2000:20:1323-7.

107. Thompson DK, Haddow JE, Smith DE, Ritchie RF. Elevated serum acute phase protein levels as predictors of disseminated breast cancer. Cancer. 1983;51:2100-4.

108. Bree F, Jouin G, Barre J, Moretti JL, Wirquin V, Tillement JP. Pharmacokinetics of intravenously administered 125I-labelled human alpha 1-acid glycoprotein. Clin Pharmacokinet. 1986;11(4): $336-42$.

109. Weisman S, Goldsmith B, Winzler R, Lepper MH. Turnover of plasma orosomucoid im man. J Lab Clin Med. 1986;57:7-15.

110. Kaysen GA, Dubin JA, Muller HG, Mitch WE, Levin NW. Levels of $\alpha 1$ acid glycoprotein and ceruloplasmin predict future albumin levels in hemodialysis patients. Kidney Int. 2001;60:2360-6.

111. McCurdy TR, Bhakta V, Eltringham-Smith LJ, Gataiance S, Fox-Robicaud AE, Sheffield WP. In vivo clearance of alpha-1 acid glycoprotein is influenced by the extent of its N-linked glycosylation and by its interaction with the vessel wall. J Biomed Biotechnol. 2012;2012:1-12.

112. Regoeczi E, Hatton MWG, Charlwood PA. Carbohydrate mediated elimination of avian plasma glycoprotein in mammals. Nature. 1975:254(5502):699-701.

113. Smith DA, Di L, Kerns EH. The effect of plasma protein binding on in vivo efficacy: miconceptions in drug discovery. Nat Rev. 2010;9:929-39.

114. Liu X, Chen C, Hop C. Do we need to optimize plasma and tissue binding in drug discovery? Curr Top Med Chem. 2011;11:45066.

115. Liu X, Wright M, Hop C. Rational use of plasma protein and tissue binding data in drug design. J Med Chem. 2014;57(20): 8238-48.

116. Di L, Breen C, Chambers R, Eckley ST, Fricke R, Ghosh A, et al. Industry perspective on contemporary protein-binding methodologies: considerations for regulatory drug-drug interaction and related guidelines on highly bound drugs. J Pharm Sci. 2017;106: 3442-52.

117. Kilford P, Andrews S, Welton G, Glazier A, Lankester D. The importance of $\mathrm{pH}$ control for accurate assessment of in vitro protein binding. Poster \#149 presented at $12^{\text {th }}$ European International Society for the Study of Xenobiotics Meeting, 2012, Noordwijjk, Netherlands.

118. Belpaire FM, DeRick A, Dello C, Fraeyman N, Bogaert MG. $\alpha 1$ acid glycoprotein and serum binding in healthy and diseased dogs. J Vet Pharmacol Ther. 1987;10:43-8.
119. Berry LM, Li C, Zhao Z. Species differences in distribution and prediction of human V (ss) from preclinical data. Drug Metab Dispos. 2011;39(11):2103-16.

120. Marier JF, Pichette V, du Souich P. Stereoselective disposition of propranolol in rabbits. Role of presystemic organs and dose. Drug Metab Dispos. 1998;26(2):164-9.

121. Akabane T, Tabata K, Kadono K, Sakuda S, Terashita S, Teramura T. A comparison of pharmacokinetics between humans and monkeys. Drug Metab Dispos. 2010;38(2):308-16.

122. Kariv I, Cao H, Oldenburg KR. Development of a high throughput equilibrium dialysis method. J Pharm Sci. 2001;90(5):580-7.

123. Colangeo PM, Blouin RA, Steinmetz JE, McNamara PJ, DeMaria AN, Wedlund PJ. Age and propranolol stereoselective disposition in humans. Clin Pharmacol Ther. 1992;51(5):489-94.

124. Chan E, McLachlan AJ, Pegg M, MacKay AD, Cole RB, Rowland M. Disposition of warfarin enantiomers and metabolites in patients during multiple dosing with rac-warfarin. Br J Clin Pharmacol. 1994;37(6):563-9.

125. Pardridge WM, Landaw EM. Tracer kinetic model of blood-brain barrier transport of plasma protein-bound ligands. J Clin Invest. 1984;74:745-52.

126. Israili ZH, Dayton PG. Human alpha-1-glycoprotein and its interactions with drugs. Drug Metab Rev. 2001;33(2):161-235.

127. Butler P, Frost K, Barnes K, Smith SA, Rioux N, Waters NJ. Impact of blood collection method on human plasma protein binding for compounds preferentially binding to $\alpha 1$-acid glycoprotein. Drug Metab Rev. 2015;48(sup 1, ISSX):28-157, Poster 77. https://doi.org/10.1080/03602532.2016.1191843.

128. Ingram N, Huskin M, Hutzler M, Smith S, Dishinger C, Wood J. Effect of the plasticizer DEHP in blood collection bags on human plasma fraction unbound determination for Alpha-1-Acid Glycoprotein (AAG) binding drugs. AAPS Annual Meeting and Exposition, 2016; Poster 36T0400.

129. Bowen RAR, Remaley AT. Interferences from blood collection tube components on clinical chemistry assays. Biochem Med. 2014;24(1):31-44.

130. Sager G, Little C. The effect of the plasticizers TBEP (tris-(2butoxyethyl)-phosphate) and DEHP (di-(2-ethylhexyl)-phthalate) on beta-adrenergic ligand binding to alpha 1-acid glycoprotein and mononuclear leukocytes. Biochem Pharmacol. 1989;38(15): 2551-7.

131. Shah VP, Knapp G, Skelly JP, Cabana BE. Interference with measurements of certain drugs in plasma by a plasticizer in vacutainer tubes. Clin Chem. 1982;28:2327-8.

132. Devine JE. Drug-protein binding interferences caused by the plasticizer TBEP. Clin Biochem. 1984;17:345-7.

133. Bhaskaran N, Vidya R, Ashalatha PM. Hexamoll DINCH plasticized PVC containers for the storage of platelets. Asian J Transfus Sci. 2011;51:18-22.

134. Ding X, Chou B, Graham RA, Cheeti S, Percey S, Matassa LC, et al. Determination of GDC-0449, a small molecule inhibitor of the hedgehog signaling pathway, in human plasma by solid phase extraction-liquied chromatographic-tandem mass spectrometry. J Chromatogr B Analyt Technol Biomed Life Sci. 2010;878:78590.

135. Wong H, Chen JZ, Chou B, Halladay JS, Kenny JR, La H, et al. Preclinical assessment of the absorption, distribution, metabolism and excretion of GDC-0449 (2-chloro-N-(4-chloro-3-(pyridin-2yl)phenyl)-4-(methylsulfonyl) benzamide), an orally bioavailable systemic hedgehog signaling pathway inhibitor. Xenobiotica. 2009;39(11):850-61.

136. Graham RA, Lum B, Cheeti S, Jin JY, Jorga K, Von Hoff DD, et al. Pharmacokinetics of hedgehog pathway inhibitor vismodegib (GDC-0449) in patients with locally advanced or metastatic solid tumors: the role of alpha-1-acid glycoprotein binding. Clin Cancer Res. 2011;17(8):2512-20. 
137. LoRusso PM, Rudin CM, Reddy JC, Tibes R, Weiss GJ, Borad $\mathrm{MJ}$, et al. Phase 1 trial of hedgehog pathway inhibitor vismodegib (GDC-0449) in patients with refractory, locally advanced or metastatic solid tumors. Clin Cancer Res. 201 1;17:2502-11.

138. LoRusso PM, Jimeno A, Dy G, Adjei A, Berlin J, Leichman L, et al. Pharmacokinetic dose-scheduling of hedgehog pathway inhibitor vismodegib (GDC-0449) in patients with locally advanced or metastatic solid tumors. Clin Cancer Res. 2011;17:5774-82.

139. Gianetti AM, Wong H, Dijkgraaf GJP, Dueber EC, Ortwine DF, Bravo BJ, et al. Identification, characterization, and implications of species-dependent plasma protein binding of the oral hedgehog pathway inhibitor vismodegib (GDG-0449). J Med Chem. 201 1;54(8):2592-601.

140. Graham RA, Hop CE, Borin MT, Lum BL, Colburn D, Chang I, et al. Single and multiple dose intravenous and oral pharmacokinetics of the hedgehog pathway inhibitor vismodegib in healthy female subjects. Br J Clin Pharmacol. 2012;74(5):788-96.

141. Wong H, Alicke B, West KA, Pacheco P, La H, Januario T, et al. Pharmaokinetic-phamacodyanic analysis of vismodegib in preclinical models of mutational and ligand-dependent hedgehog pathway activation. Clin Cancer Res. 201 1;17(14):4682-92.

142. Kurata N, Kuwabara T, Tanii H, Fuse E, Akiyama T, Akinaga S, et al. Pharmacokinetcs and pharmacodynamics of a novel protein kinase inhibitor, UCN-01. Cancer Chemother Pharmacol. 1999;44:12-8.

143. Sausville EA, Arbuck SG, Messmann R, Headlee D, Baver KS, Lush RM, et al. Phase I trial of 72-hour continuous infusion UCN01 in patients with refractory neoplasms. Clin Cancer Res. 2001;7: 1867-72.

144. Fuse E, Tanni H, Kurata N, Kobayashi H, Shimada Y, Tamura $\mathrm{T}$, et al. Unpredicted clinical pharmacology of UCN-01 caused by specific binding to human alpha 1-acid glycoprotein. Cancer Res. 1998;58:3248-53.

145. Fuse E, Tanii H, Takai K, Asanome K, Kurata N, Kobayashi H, et al. Altered pharmacokinetics of a novel anticancer drug, UCN01 , caused by specific high affinity to alpha 1-acid glycoprotein in human. Cancer Res. 1999;59:1054-60.

146. Fuse E, Kuwabara T, Sparreboom A, Sausville EA, Figg WD. Review of UCN-01 development: a lesson in the importance of clinical pharmacology. J Clin Pharmacol. 2005;45:394-403.

147. Sparreboom A, Chen H, Acharya MR, Senderowicz AM, Messman RA, Kuwabara T, et al. Effects of a l-acid glycoprotein on the clinical pharmacokinetics of 7-hydroxystaurosporine. Clin Cancer Res. 2001;10:6840-6.

148. Yasoshima K, Kuwabar T, Fuse E, Kuramitu T, Kurata N, Nishiie $\mathrm{H}$, et al. Pharmacokinetics, distribution, metabolism and excretion of $\left[{ }^{3} \mathrm{H}\right] \mathrm{UCN}-01$ in rats and dogs after intravenous administration. Cancer Chemother Pharmacol. 2001;47:106-12.

149. Heinrich MC, Griffith DJ, Druker BJ, Wait GL, Ott KA, Zigler AJ. Inhibition of c-kit receptor tyrosine kinase activity by STI 571, a selective kinase inhibitor. Blood. 2000;96:925-32.

150. Delbaldo C, Chatelut E, Re M, Deroussent A, Seronie-Vivien S, Jambu A, et al. Pharmacokinetic-pharmacodynamic relationships of imatinib and its main metabolite in patients with advanced gastrointestinal stromal tumors. Clin Cancer Res. 2006;12: 6073-8.

151. Fitos I, Visy J, Zsila F, Mady G, Simonyi M. Selective binding of imatinib to the genetic variants of human alpha 1-acid glycloprotein. Biochim Biophys Acta. 2006;1760:1704-12.

152. Peng B, Lloyd P, Schran H. Clinical pharmacokinetics of imatinib. Clin Pharmacokinet. 2005;44:879-94.

153. Frye RF, Fitzgerald SM, Lagattuta TF, Hruska MW, Egorin MJ. Effect of St John's wort on imatinib mesylate pharmacokinetics. Clin Pharmacol Ther. 2004;76:323-9.

154. Petain A, Kattygnarath D, Azard J, Chatelut E, Delbaldo C, Geoerger B, et al. Population pharmacokinetics and pharmacogenetics of imatinib in children and adults. Clin Cancer Res. 2008; 14:7101-9.

155. Gurnery H, Wong M, Balleine RL, Rivory LP, McLachlan AJ, Hoskins JM, et al. Imatinib disposition and ABCBA (MDR1, Pglycoprotein) genotype. Clin Pharmacol Ther. 2007;82:33-40.

156. Widmer N, Decosterd LA, Csajka C, Leyvraz S, Duchosal MA, Rosselet A, et al. Population pharmacokinetics of imatinib and the role of alpha-acid glycoprotein. Br J Clin Pharmacol. 2006;62:97112.

157. Le Coutre P, Kreuzer KA, Na IK, Lupberger J, Holdhoff M, Appelt $\mathrm{G}$, et al. Determination of alpha-1 acid glycoprotein in patients with $\mathrm{Ph}+$ chronic myeloid leukemia during the first 13 weeks of therapy with ST1571. Blood Cells Mol Dis. 2002;28:7585.

158. Larghero J, Leguay T, Mourah S, Madelaine-Chambrin I, Taksin AL, Raffoux E, et al. Relationship between elevated levels of the alpha 1 acid glycoprotein in chronic myelogenous leukemia in blast crisis and pharmacological resistance to imatinib (Gleevec) in vitro and in vivo. Biochem Pharmacol. 2003;66:1907-13.

159. Smith SA, Gagnon S, Waters NJ. Mechanistic investigations into the species differences in pinometostat clearance: impact of binding to alpha-1-acid glycoprotein and permeability-limited hepatic uptake. Xenobiotica. 2016;47(3):185-93. 